Louisiana State University

LSU Digital Commons

\title{
The Value of Salt Marsh Edge vs Interior as a Habitat for Fish and Decapod Crustaceans in a Louisiana Tidal Marsh
}

\author{
G. W. Peterson \\ R. Eugene Turner \\ euturne@lsu.edu
}

Follow this and additional works at: https://digitalcommons.Isu.edu/oceanography_coastal_pubs

Part of the Oceanography Commons

\section{Recommended Citation}

Peterson, G. W., \& Turner, R. (1994). The Value of Salt Marsh Edge vs Interior as a Habitat for Fish and Decapod Crustaceans in a Louisiana Tidal Marsh. Estuaries, 17 (1B), 235-262. Retrieved from https://digitalcommons.Isu.edu/oceanography_coastal_pubs/152

This Article is brought to you for free and open access by the Department of Oceanography \& Coastal Sciences at LSU Digital Commons. It has been accepted for inclusion in Faculty Publications by an authorized administrator of LSU Digital Commons. For more information, please contact ir@lsu.edu. 


\title{
The Value of Salt Marsh Edge vs
}

\section{Interior as a Habitat for Fish and}

\section{Decapod Crustaceans in a}

\section{Louisiana Tidal Marsh}

\author{
G. W. Phtrerson \\ R. H. TERver \\ Coastal Fcology Institute \\ Center for Coastal Energy and Environmental Research \\ Louisiana State University \\ Baton Rouge, Louisiana 70803
}

\begin{abstract}
Flume nets of various lengths and a 3-m seine were used to sample the fishes and macrocrustaceans using a flooded Louisiana salt marsh and the adjacent tidal creek. The experiment allowed for species-specific comparisons of the flooded marsh at the creek edge versus the interior. Of the 37,667 organisms collected in flume nets from January through November 1989, 89\% were decapods (nine species) and $11 \%$ were fish (29 species). An additional 18,539 organisms (75\% decapods and $25 \%$ fish) were collected from concurrent seine samples taken from July through November. Comparison of catches among different flume lengths and low tide versus high tide seine collections revealed distinct patterns of marsh habitat utilization. Densities of most organisms were highest within $3 \mathrm{~m}$ of the water's edge, but significant numbers of marsh-resident fish species used the interior marshes. The edge marshes appeared to be used by both transient and resident species; however, the interior marshes were used primarily by marsh-resident species (Cyprinodontiformes and Palaemonetes sp.) that are excellent food sources for adult transient-species. Four zonations of marsh use are described for transients, residents, and rare species.
\end{abstract}

\section{Introduction}

Shallow-water, salt-marsh habitats are known to be important nursery areas for estuarine fish and crustaceans (Herke 1971; Wcinstein 1979; Boreman and Dean 1980; Turner 1992). The traditionally accepted role of emergent marsh vegetation supporting estuarine fisheries productivity via detrital-based food chains (Darnell 1958, 1961, 1967; Odum and Heald 1975) has been questioned (Nixon 1980; Boesch and Turner 1984), and more recent attention has focused on the direct use of intertidal marshes by fishes and invertebrates for fceding, reproduction, and refugc from predators. Recently developed methods for sampling in emergent vegetation, including pit traps (Kneib and Stiven 1978), drop samplers (Zimmerman et al. 1984), flume nets (McIvor and Odum 1986), block-nets (Hettler 1989), flume-weirs (Kneib 1991), and lift nets (Rozas 1992a) have shown that juvenile and small adult fishes and invertebrates use flooded marsh habitats.

Results from the new gear types are not necessarily comparable. Pit traps are effective for catching killifishes (Cyprinodontidae) and other marshresident species that use flooded marshes and return to marsh ponds and ditches at low tide
(Kneib and Stiven 1978; Kneib 1984; Talbot and Able 1984). Pit traps are probably not effective at catching transient species that move from tidal creeks and bays up onto the marsh at high tide and return to open-water areas on ebbing tides. Studies in 'Texas that utilized paired drop samplers on flooded salt marshes reported higher densities of grass shrimp, blue crabs, and brown shrimp in vegetated marsh habitats when compared to adjacent nonvegetated habitats (7immerman et al. 1984; Zimmerman and Mincllo 1984). Drop samplers are very quantitative but sample a relatively small area $\left(0.5-2.8 \mathrm{~m}^{2}\right)$, and, because they are usually dropped from a boat, they are only effective for sampling the edge of marshes. McIvor and Odum (1986) developed flume nets to passively sample fish from intertidal freshwater marshes in Virginia. They reported extensive use of flooded marshes by resident, freshwater species, as well as by some estuarine, transient fishes and crustaceans. Hettler (1989) collected fish coming off a flooded salt marsh in North Carolina with a modified block-net and reported extensive use of these marshes by both resident and transient fishes and crustaceans. Both flume nets and block nets utilize tidal action to passively (and nondestructively) 
sample large areas of vegetated marsh, and have proven effective in marshes that flood regularly. These two approaches cannot determine which fish utilize only the edge marshes and which (if any) penctrate into the interior marshes becausc the entire catch is consolidated into one net at the creckbank.

Two new gear types were described after this study was initiated that quantitatively and nondestructively sample fish on the flooded marsh surface. These two passive methods enclose the marsh at high tide and concentrate the sample into pit traps located at the lowest clcvation inside the cnclosure as the marsh drains. The flume-weir (Kneib 1991), enclosing $100 \mathrm{~m}^{2}$ of marsh, uses screen panels inserted into frames from a boardwalk. The lift net gear (Roras 1992a) is buried in the marsh and is remotely lifted to enclose $6 \mathrm{~m}^{2}$ of marsh. These gear are without permanent walls to block access to the marsh and can discretely sample the edge and interior marshes. They are, therefore, probably more effective than flumes and block nets for sampling fishes using interior marshes.

Data were collected using flumes and seines to address three objectives: to quantify the temporal and spatial use of the flooded marsh surface by fishes and crustaceans in a natural I ouisiana saline marsh; to compare the relative importance of the marsh habitat at the creck edge versus the interior marshes; and to identify species-specific differences in marsh habitat use. We were particularly interested in comparing spatial marsh use by resident and estuarine-dependent species. Our basic hypothesis was that there are species-specific differences in marsh use, that is, not all species will use the marsh edge exclusively and not all species distribute themselves homogeneously over the marsh during flooding (Hypothesis \#1). We further hypothesized that the edge marshes are more important to fishes and crustaceans (particularly transient, estuarine-dependent species) than are the interior marshes (Hypothesis \#2), and the interior marshes are utilized primarily by marsh-resident species (Hypothesis \#3).

\section{Materials and Methods \\ STUdy AREA, SAMPLE GEAR, ANI) SitF. SFi.F.TIION}

The study area was in a saline marsh approximately $2 \mathrm{~km}$ NNW of the Louisiana Lniversities Marine Consortium (LUMCON) Marine Center in Cocodrie, Louisiana (Fig. 1). The streamside edge and interior marsh vegetation is dominated by Spartina alterniflora and along the natural levee is a mixed S. alterniflora, Spartina patens and Distichlis spicata community. The experiment used flume nets of different lengths to allow comparisons between edge and interior marshes. Samples were also collected by seining at high and low tides along the creck edge adjacent to the flumes to allow comparisons of the species composition at the creek edge with that of the adjacent flooded marsh. Flume nets were constructed in a relatively uniform marsh adjacent to a nearly straight stretch of creek bank (approximately $175 \mathrm{~m}$ long) with a gradual sloping shoreline profilc. This site was chosen to increase the chances that all flumes would sample similar habitats (shoreline conditions, vegetation stem density and biomass). Results from flume net studies in Virginia tidal freshwater marshes report that stream-order, shoreline profiles (erosional vs depositional), and drainage features (rivulets vs creekbanks) have significant effects on the densities of nekton utilizing the adjacent marshes (Rozas and Odum 1987; McIvor and Odum 1988; Rozas et al. 1988). Rozas et al. (1988) reported densities of fish to be three times greater in rivulet flumes than in creekbank flumes, but because of the relatively low density of rivulets, they estimated that $88 \%$ of fishes reached the marsh surface via creckbanks; therefore, all flumes used in this study were constructed on creekbanks without rivulets. Because marshes adjacent to gradually sloping shorclines (depositional) arc utilized more by fish than those adjacent to steep erosional shorelines (McIvor and Odum 1988), a site was selected along a straight stretch of creekbank to assure that all flumes had similar shoreline profiles.

\section{FLLME NF.T SAMPI.ING}

Flume nets, modified from the design by McIvor and Odum (1986), were uscd to quantitatively and nondestructively sample the fishes and macrocrustaceans using the flooded marsh surface. The flume nets consisted of parallel walls of 3 -mm-mesh plastic aquaculture netting oriented perpendicular to the creek axis. The net walls were attached to 5 $\mathrm{cm} \times 5 \mathrm{~cm}$ wooden posts spaced $2 \mathrm{~m}$ apart and the bottom $10-15 \mathrm{~cm}$ was buried in the marsh sediment, resulting in walls approximately $0.75 \mathrm{~m}$ high. These flume walls remained in the marsh throughout the study. The ends of the flumes remained open except when they were being "fished." At this time a cod-cnd net constructed from 3-mm-mesh nylon netting attached to a rectangular PVC-pipe frame $(2 \mathrm{~m} \times 0.915 \mathrm{~m})$ was attached to cach end of the flume using a sliding PVC track similar to that described by McIvor and Odum (1986). An A-frame was added (after 2 mo of sampling) at each end of the flumes to suspend the cod-end net over the opening and to allow remote setting of the ncts, thus minimizing organism disturbance. The nets were suspended in the slid- 


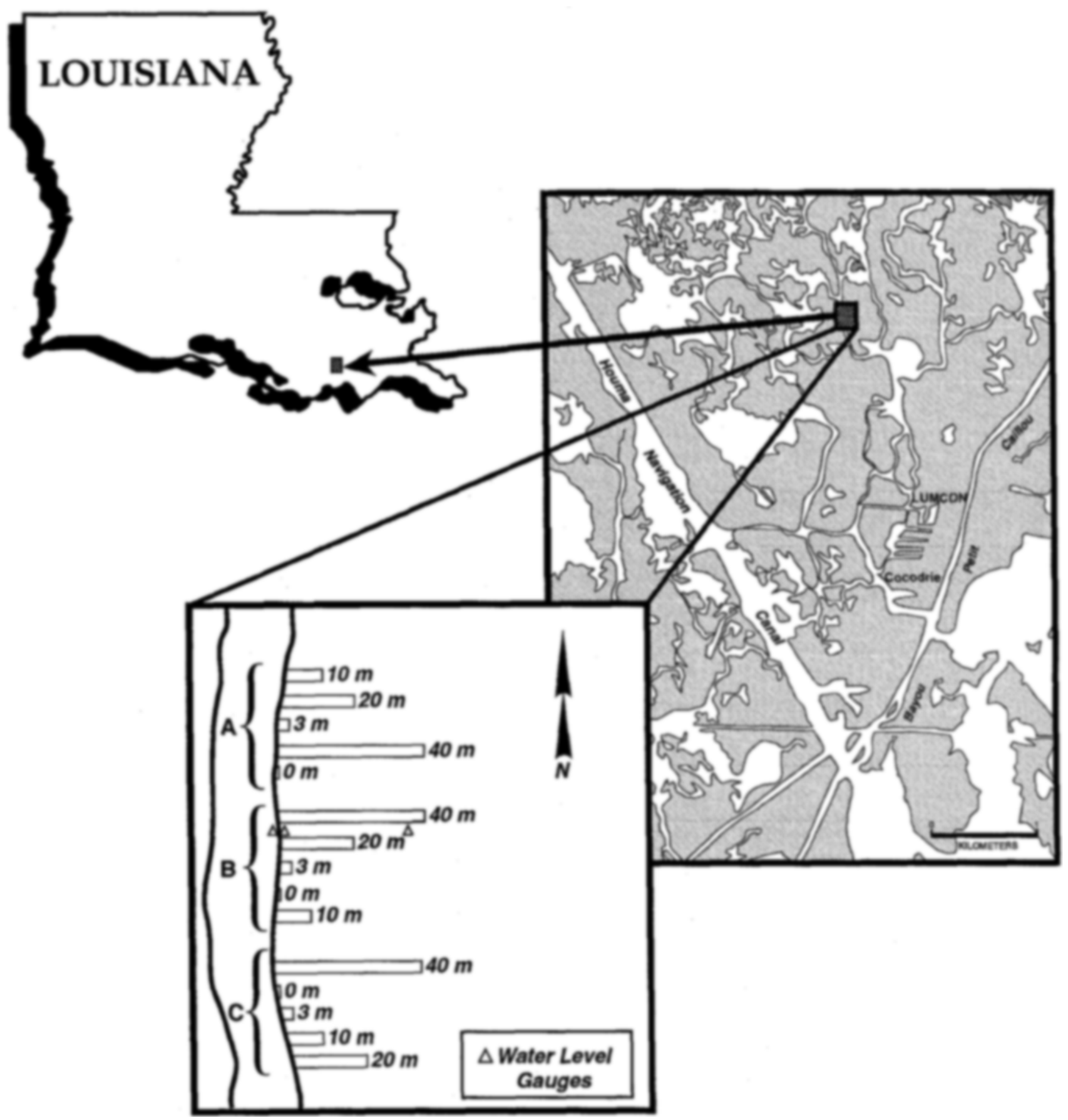

Fig. 1. I ecation of the study area and watcr-lewel gauges, and a diagram of the experimental design showing the randomized placement of five flume length treatments within three blocks $(A, B, C$ ).

ing tracks by bridles and attached to the A-fiames with release pins that werc tripped remotely with a $4.5-\mathrm{m}$ long cord.

The flume ncts used in this study differed from those described by McIvor and Odum (1986). The mesh size was smaller $(3 \mathrm{~mm}$ ys $6 \mathrm{~mm}$ ), the flumes wider $(2 \mathrm{~m}$ vs $1.5 \mathrm{~m})$, the length varied $(0 \mathrm{~m}, 3 \mathrm{~m}$,
$10 \mathrm{~m}, 20 \mathrm{ml}$, and $40 \mathrm{~m}$ vs $20 \mathrm{~m}$ ), and both ends remained open during the flood tide (as opposed to being open only at the creek bank). The experiment was a randomized block design with three blocks of five trcatments. consisting of flumes extending $0 \mathrm{~m}$ (no flume), $3 \mathrm{~m}, 10 \mathrm{~m}, 20 \mathrm{~m}$, and 40 $m$ into the marsh (Fig. 1). Fhumes were spraced ap- 
proximately $10 \mathrm{~m}$ apart within treatment blocks, with approximately $20 \mathrm{~m}$ between blocks.

Each flume had a boardwalk to minimize damage to the marsh during construction and monthly inspection. Walkway planks were used only during the construction, on monthly inspections, and while setting and retrieving of nets to eliminate the possible effects of shading.

The flumes were "fished" by letting both ends of the flume remain open during flood tides, closing both ends at or near slack high tides, and then picking up the cod-end nets after the marsh drained (at or near low tide). Because the "natural levec" of the creek (approximately $3 \mathrm{~m}$ in from the edge) had a slightly higher elevation than the interior marshes, it was necessary to use cod-end nets on both ends of the long flumes $(10 \mathrm{~m}, 20 \mathrm{~m}$, and $40 \mathrm{~m}$ ). The 3-m flumes had a cod-end net on the creek end and a flat block-net on the marsh end. The no-flume $(0 \mathrm{~m})$ treatment consisted of a cod-end net attached to end posts placed at the edge of the creek (with no flume walls attached).

The underlying assumptions for making conparisons between flume lengths were that access to all flumes $(3 \mathrm{~m}, 10 \mathrm{~m}, 20 \mathrm{~m}$, and $40 \mathrm{~m})$ was equal for organisms entering the marsh from the creek bank (or from the interior marsh), and that these flumes neither attract nor deter aquatic organisms to use the marsh. Because both ends remain open until the nets are set at high tide, an organism entering the marsh from the creek could move inland unrestrained and would only be captured if it remained within that particular flume (i.e., a fish entering a 3-m flume will not be captured if it. moves inland $10 \mathrm{~m}$ ). Therefore, if an organism entered the marsh over the creck bank and used the edge and interior marshes homogeneously, catches will be proportional to length. Converscly, catchcs will be equal in all flume lengths if only the edge marshes ( $<3 \mathrm{~m}$ from the creek) are used.

Catches are reported as numbers and biomass per $2 \mathrm{~m}$ of marsh edge (as did McIvor and Odum 1986) not per unit area of marsh. This was done because the flume walls restrict the lateral movement of fish over the marsh surface. Because all flumes had the same width (regardless of length), comparisons among treatments were made with actual numbers (log-transformed) captured.

Sampling was conducted approximately monthly during the tidal cycle with the highest predicted tidal height and range. The sampling dates were sclected based on tides predicted by the United States Department of Commerce, National Occan Survey from the gauge at the ILUMCON Marine Center. Samples were collected monthly from all 15 flumes beginning in January 1989; in March 1989, net deployment was modified to allow re- mote setting of the nets. Data from January through November 1989 are presented here.

\section{Seinf: SAMPLing;}

Some fish captured in flume nets may not have been on the marsh surface because the design of the flume nets (straight net framc along an irregularly shaped marsh edge) results in a small amount of creek-cdge habitat being sampled. Species that are infrequently caught in flumes may be a result of this phenomenon. This design flaw became evident after a few months of sampling. We therefore supplemented the flume sampling with high-tide and low-tide seine sampling along the creek-cdge habitat beginning in July 1989.

Our working assumptions about the results from the seining were that fish using the marsh surface at high tide will be scarce in high-tide samples and much more abundant in low-tide samples when they are forced out of the marsh, that species using only the creck-edge habitat will be equally abundant at high and low tides, and that species preferring decper, more open-water habitats will be rare in low-tide scine samples but more abundant in high-tide samples when the water at the cdge is deeper.

Scine samples were collected adjacent to the flumes at high and low tide every time the flume nets were fished to allow comparisons of the species composition and abundance at different tide stages and between these two gear types. Iwo seine stations were permancntly established along the creck edge adjacent to the flumes, one north and one south of the flumes on the same side of the creek. One scinc sample was collected at each station at high tide, immediately after setting the flume nets, and again at low tide, immediatcly before retrieving the flume net samples. Seine samples were collected with a $3 \mathrm{~m} \times 2 \mathrm{~m}$ straight scine with $3.2-\mathrm{mm}$ nylon ace mesh pulled along the creek edge by two persons, one walking on the marsh edge and one in the creek approximately 2 $\mathrm{m}$ from shore. Each sample covered $30 \mathrm{~m}$ of creek edge and was collected in threc short drags (approximately $10 \mathrm{~m}$ each) that were pooled together.

All animals collected in flume or seine samples were preserved in the field in $10 \%$ formalin and transported to the laboratory where they were sorted, identified, counted, measured, and weighed.

\section{Pimsicai, Data Colificton}

Endeco Type 1152 Density Compensating Water-Lcvel Recorders were installed $1 \mathrm{~m}$ into the creek, $1 \mathrm{~m}$ into the marsh, and $35 \mathrm{~m}$ into the marsh alone one boardwalk near the center of the flume site (Fig. 1). An identical gauge was installed approximately $2 \mathrm{~km}$ away in the creck near the 
LUMCON Marine Center. These gauges provided a continuous record of the frequency, amplitude, and duration of flooding events, as well as water salinity and temperature. A water-salinity sample was taken from the creek at the flume site at high tide (when the flume nets were set) and again at low tide (when the nets were retrieved). Salinity was measured in the laboratory with a Haake-Buchler Digital Chloridometer.

\section{DATA Anai.rsis}

Analysis of the data was on the Louisiana State University (ISU) mainframe computer using the Statistical Analysis System package (SAS Institutc Inc. 1985a, b, c). All analysis of variance (ANOVA) and regrcssion models were run with the general linear models (GI.M) procedure. All catch data was log-transformed prior to analysis. Comparisons of catches were made between flume length treatments (FIEXGTH) with a factorial ANOVA model to test the hypothesis that the cdgc marshes are more important to transient fishes and decapod crustaceans than are interior marshes. Comparisons were also made between catches from front (creck bank) nets and back (interior marsh) nets from those flumes that had both front and back nets (10-m, 20-m, and 40-m flumes only). Because the flume net experiment was set up in a randomized block design, all ANOVA models included REP as a blocking factor to remove any block offects (and as a test of the sampling error). An ANOVA was also used to test for differences between high-tide and low-tide catches from seine samples. Because seasonal differences in species abundance were expected, DATE was included as a main effect in all models as was its interaction with other main effects. These ANOVA models were run on various subsets of the data including log-transformed numbers of decapods only, fish only, "transient" fish only, "resident" fish only, and individual species. Because of the potential problem of tinding a significant result by chance alone when running multiple ANOVAs, a Bonferroni-adjusted alpha level was used to assure a $95 \%$ confidence level for the individual species $\Lambda \mathrm{NO}$ VAs $(p<0.0025$ for flume data; $p<0.0036$ for seine data). ANOVA tables are not presented here; instead, F-values and probability levels are given when appropriate.

Resident species are generally defined as those that spend their entire life cycle in the estuary; transient species are those that spend only some life stages (c.g., juvenile) in the estuary. In this report, fish species were classified as either "resident" or "transient" based on an ecological classification in Thompson and Forman (1987), who classified fish from the Barataria Bay basin into four groups. The resident classification included any species listed in their "estuarine" and "freshwater" classifications; the transient classification included those fish species classified as "estuarinemarine" or "marine" in Thompson and Forman (1987).

\section{Results \\ Physicai. Data}

The data presented herc are from the LLMCON Marine Center gauge that had the most complete data sct. There were data collection problems with the three gauges (located in the creek, at the marsh edge, and in the interior marshes) at the flume sitc. Several months of water-level data from these gauges were usable and were compared with data from the gauge in the bayou at I.UMCON. Water levels at the two sites were highly coherent at diurnal tidal frequencies $\left(\mathrm{R}^{2}>0.95\right)$. $A$ nearly complete continuous record (15-min intervals) of water levels from January through December 1989 is presented in Fig. 2. This figure illustrates the frequency, depth, and duration of flooding cvents, and the times when flume net samples were taken. The horizontal line on Fig. 2 (at 0-cm water level) approximates the average interior marsh elevation (the level at which the 35-m inland gauge was sct). The maximum water depth on the marsh at high tide (typically diurnal) ranged from less than zero (not flooded) to approximately $54 \mathrm{~cm}$ during the period of study (January through November 1989). The maximum water depths during the tidal cycles when flume net samples were collected ranged from $6.9 \mathrm{~cm}$ in February to $34.5 \mathrm{~cm}$ in November 1989 .

Figure $3 \mathrm{~A}$ illustrates the mean marsh-elevation profiles for each flume (each line is a mean of two profiles within each flume). Although individual flume profiles are not readily distinguishable from this figure (all five flumes within each block have the same line pattern), the variation in flume clcvations along the transects is gencrally $<10 \mathrm{~cm}$. A wcll-defined natural levec, approximately 10-15 $\mathrm{cm}$ higher than the interior marsh elevation, is cvident with its peak located about $3 \mathrm{~m}$ from the creek edge. Since the "zero elevation" reference line in Fig. $3 \Lambda$ corresponds to the "zero water lcvel" reference line in Fig. 2, it is obvious that a high tide flooding depth $<10-15 \mathrm{~cm}$ would not flood the natural levee. However, even at these lower water levels, the interior marsh does flood "from the back" through small drainage features such as rivulets and muskrat trails.

Salinity and temperature data from the I.UMCON gauge were also recorded for January through December 1989. Salinity during that time 

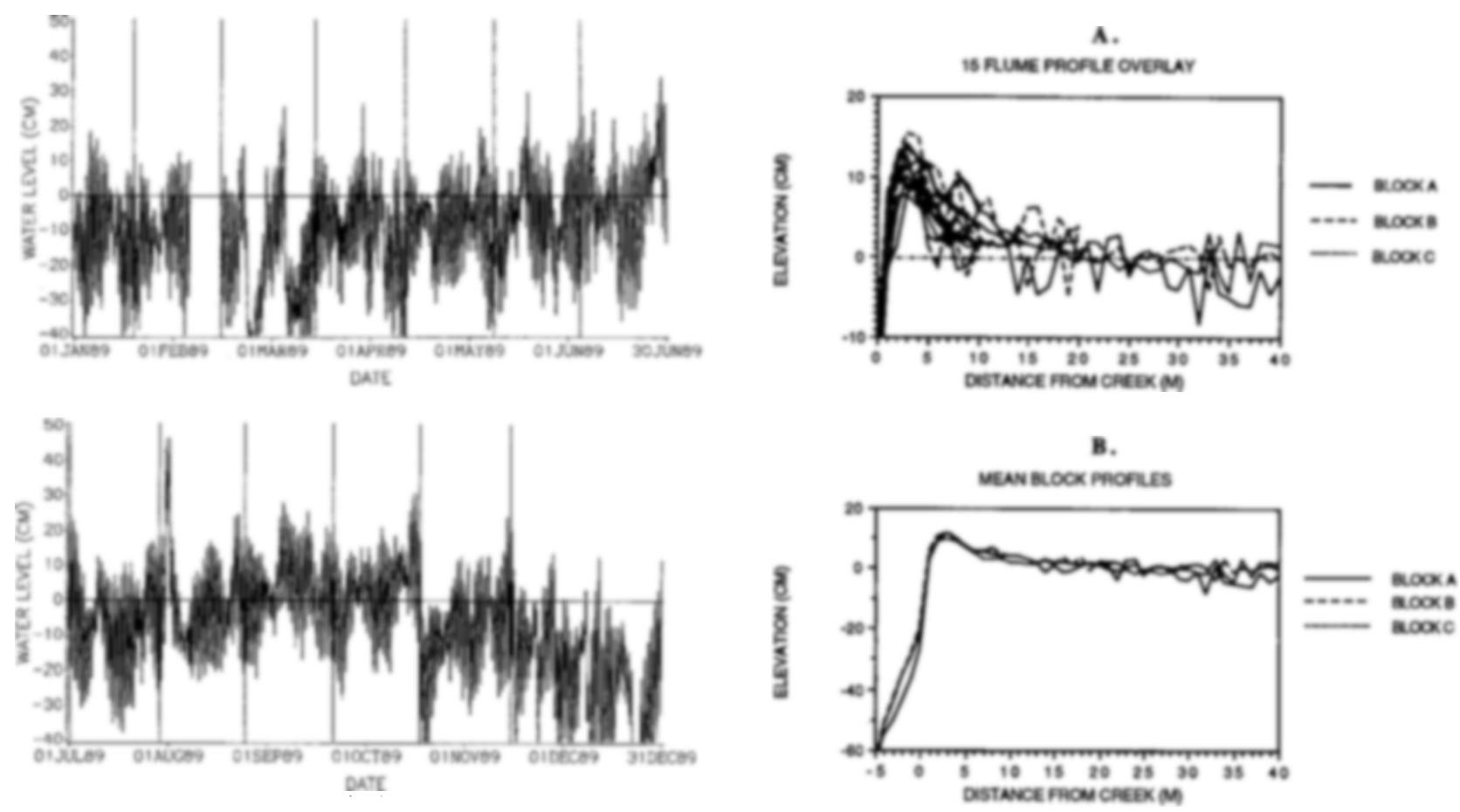

Fig. 2. Water-level data for 1989 at the LLMCON gange. The horizontal line represents the approximate marsh surface elevation at the flume site. The vertical lines indicate the times when the flume net samples were collected.

ranged from $0.8 \%$ in July to $20.6 \%$ in October. Actual salinities at the site during flume net collections varied from $2.0 \%$ in April to $18.1 \%$ in October. Temperatures at the I.UMCON gauge ranged from $34.4^{\circ} \mathrm{C}$ in $\Lambda$ ugust to $0^{\circ} \mathrm{C}$ in December.

\section{Flume Nei Data \\ Speries Composition}

A total of 37,667 organisms (fish and decapod crustaceans) with a total preserved wet weight of $29.1 \mathrm{~kg}$ were collected in the flume nets from January through November 1989 (Table 1). The total catch included 29 species of fish $(4,124$ individuals, $6.9 \mathrm{~kg}$ preserved wet weight) representing 14 families and at least 9 species of decapod crustaccans (33,543 individuals, $22.3 \mathrm{~kg}$ preserved wet weight). Other taxa of invertebrates, including Amphipoda, Isopoda, Mysidacea, Gastropoda, Bivalvia, Polychacta, Arachnida, Insecta, and Ilirudinea, and even Gulf salt-marsh snakes (Nerodia clarkii), were captured in the flume nets but were not included in the summaries and analysis of catch data. The species composition in flume net catches varied with season (Table 2). In general, marsh-resident species were more abundant and always present. Transient species were only seasonally present.

The total catch was dominated by decapod crus-

Fig. 3. Flevation levels at the flume net sites. A. Average marsh elevation profiles (two replicatc profiles) for each of 15 individual flumes, identified by llume block (A, B, or (C). B. Mean marsh and adjacent creek elevation profiles of five flumes within each flume block (each flume has two replicates).

taceans that made up $89.0 \%$ of the total number and $76.4 \%$ of the total biomass (Table 1 and Fig. 4). Grass shrimp (Palaemonetes sp.) were the most abundant organisms caught in the flumes, comprising $74.9 \%$ by number $(25.4 \%$ biomass) of the total catch; blue crabs (Callinectes sapidus) were the next most abundant at $9.9 \%$ by number $(42.9 \%$ biomass). Fish species made up only $11.0 \%$ of the total catch by number but $23.6 \%$ of the total biomass. Naked goby (Gobiosoma bosc) was the most abundant fish caught (4.4\% of total) but was fifth in biomass (1.6\% of total). 'The Gulf killifish (Fundulus grandis) was the second most abundant fish species $(1.8 \%$ of total $)$ but had the highest biomass $(7.5 \%$ of total). A single specimen of southern flounder (Paralichthys lethostigma) represented more biomass ( $1.7 \%$ of total) than all 1,649 naked gobies. Because of the problem of single large specimens dominating biomass, all comparisons and analysis are done on counts rather than biomass.

\section{Comparison of Flume Catches From Front and Back Nets}

Among those flumes that had both front and back nets (10-m, 20-m, and 40-m flumes only), sig- 
TABI.E 1. I. ist of fishes and decapod crustaceans collected from flume nets from Januany through November 1989. The total number, total hiomass (presened wet weight). and percentage of total catch by number and biomass are given for each species. Fish and decapod species are listed separately in order of decreasing numerical abundance.

\begin{tabular}{|c|c|c|c|c|}
\hline \multirow[b]{2}{*}{ speries } & \multicolumn{2}{|c|}{ Total Number } & \multicolumn{2}{|c|}{ Total Rionnasi } \\
\hline & Numlx.t & Percent & Weright (g) & Percont \\
\hline \multicolumn{5}{|l|}{ Fishes } \\
\hline Gobiosoma bose & 1,649 & 4.4 & 180.6 & 1.6 \\
\hline Fundulus grandis & 663 & 1.8 & $2,182.6$ & 7.5 \\
\hline Adinin xemicat & 450 & 1.2 & 178.4 & 0.6 \\
\hline Fundulus pnelverents & 336 & 0.9 & 165.0 & 0.6 \\
\hline Gobionellus boleosoma & 171 & 0.5 & 56.4 & 0.2 \\
\hline Poecilia latipinna & 169 & 0.4 & 116.6 & 0.4 \\
\hline Lucania pama & 132 & 0.4 & 34.6 & 0.1 \\
\hline Cyprinodon varriegatus & 116 & 0.3 & 119.6 & 0.4 \\
\hline Findulus jenkinsi & 102 & 0.3 & 63.3 & 0.2 \\
\hline Menidia benyllina & 67 & 0.2 & 42.0 & 0.1 \\
\hline Cynoscion netrulosus & 64 & 0.2 & 485.4 & 1.7 \\
\hline Nugil cephalus & 47 & 0.1 & $1,742.2$ & 6.0 \\
\hline Anchoa mitchilli & 39 & 0.1 & 10.9 & $<0.1$ \\
\hline Myrophis punctatus & 27 & 0.1 & 245.3 & 0.8 \\
\hline Bairdiella chrysonua & 20 & 0.1 & 58.3 & 0.2 \\
\hline Archosargus probatocephalus & 18 & $<0.1$ & 178.9 & 0.6 \\
\hline (rambusia affinis & 9 & $<0.1$ & 0.6 & $<0.1$ \\
\hline Citharichthys spilopterus & 9 & $<0.1$ & 39.8 & 0.1 \\
\hline Achirus lineatus & 9 & $<0.1$ & 5.2 & $<0.1$ \\
\hline Mioronogronias umdulatus & 6 & $<0.1$ & 5.1 & $<0.1$ \\
\hline Lagodon rhomboides & 5 & $<0.1$ & 75.9 & 0.3 \\
\hline (iobionellus shufeldti & 4 & $<0.1$ & 2.2 & $<0.1$ \\
\hline Simphlurus plagiusa & 4 & $<0.1$ & 1.6 & $<0.1$ \\
\hline Scialenops ocellatus & 3 & $<0.1$ & 32.0 & 0.1 \\
\hline Cynoscion arenamus & 1 & $<0.1$ & 0.8 & $<0.1$ \\
\hline Singnathus floridae & 1 & $<0.1$ & 0.7 & $<0.1$ \\
\hline Syngnathus scovelli & 1 & $<0.1$ & 0.6 & $<0.1$ \\
\hline Paralichthys lethostigma & 1 & $<0.1$ & 504.1 & 1.7 \\
\hline Opsanus beta & 1 & $<0.1$ & 47.3 & 0.2 \\
\hline \multicolumn{5}{|l|}{ Decapod crustaceans } \\
\hline Palacmonctes sp. & 28.221 & 74.9 & $7,390.0$ & 25.4 \\
\hline Callinectes sapridus & 3,714 & 9.9 & $12,505.4$ & 42.9 \\
\hline lia sp. & 804 & 2.1 & $1,737.2$ & 6.0 \\
\hline Penaens setiferus & 307 & 0.8 & 141.3 & 0.5 \\
\hline Penctertes aztecus & 252 & 0.7 & 353.5 & 1.2 \\
\hline Xanthidac & 207 & 0.5 & 45.9 & 0.2 \\
\hline Sesarma sp. & 35 & 0.1 & 90.2 & 0.3 \\
\hline Macrotnachium sp. & 2 & $<0.1$ & 0.2 & $<0.1$ \\
\hline Paguridea & 1 & $<0.1$ & 2.8 & $<0.1$ \\
\hline Iotal fish & 4,124 & 11.0 & $6,876.2$ & 23.6 \\
\hline Total decapods & 33,543 & 89.0 & $22,266.5$ & 76.4 \\
\hline Total fish and decapods & 37,667 & 100.0 & $29,142.7$ & 100.0 \\
\hline
\end{tabular}

nificantly higher numbers of decapods $(\mathrm{F}=$ $1708.74, \mathrm{p}<0.0001)$ were caught in the front nets $(94.3 \%)$ than in the back nets. Some grass shrimp and blue crabs were caught in back nets, but most $(98.9 \%$ and $90.9 \%$ respectively) were caught in the front nets (Table 3). Almost all (99.9\%) of the fiddler crabs (L/ca sp.) and $39.3 \%$ of the wharf crabs (Sesarma sp.) were caught in the back nets. Penaeid shrimp and Xanthid crabs were caught exclusively in the front nets.

Significantly higher numbers of fish $(F=183.87$, $\mathrm{p}<0.0001)$ were caught in the front nets $(68.6 \%)$ than in the back nets (Table 4 ). The 10 most abun- dant fish species (naked goby, Gobiosoma bose; gulf killifish, Fundulus grandis; diamond killifish, Adinia xenica; bayou killifish, $F$. pulvereus; sailfin molly, Poecilia latipinna; rainwater killifish, I.ucania parva; sheephead minnow, Cyprinodon variegatus; darter goby, Gobionellus boleosoma; saltmarsh topminnow, F. jenkinsi; and tidewater silverside, Menidia beryllina) accounted for $94.4 \%$ of the total fish catch from the $10-\mathrm{m}, 20-\mathrm{m}$, and $40-\mathrm{m}$ flumes ('Table 4 ). These 10 species were classified as resident species and represent four familics (Cyprinodontidae, Crobiidac, Poecilidae, and Atherinidac). Resident fish species were caught in significantly higher num- 


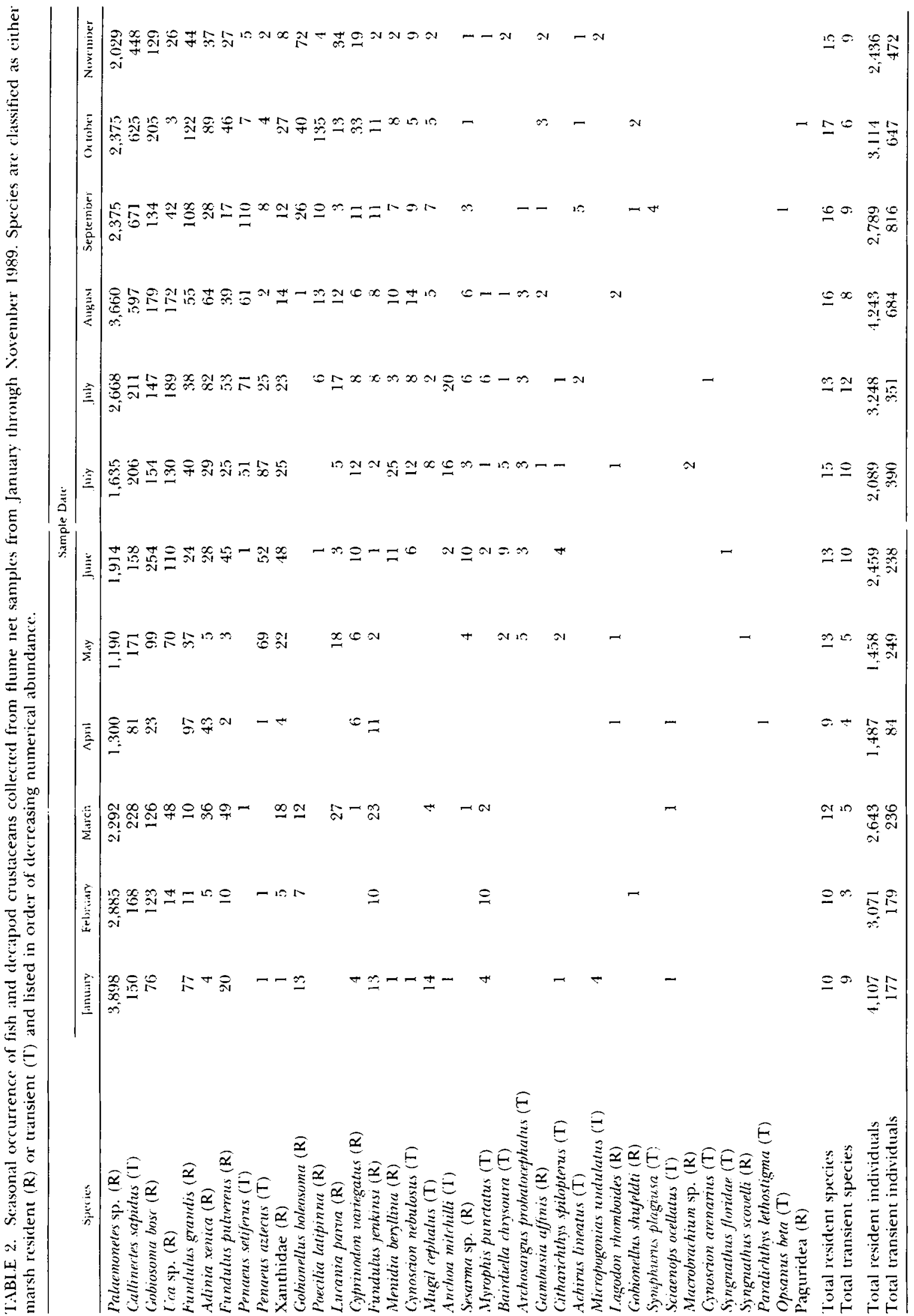




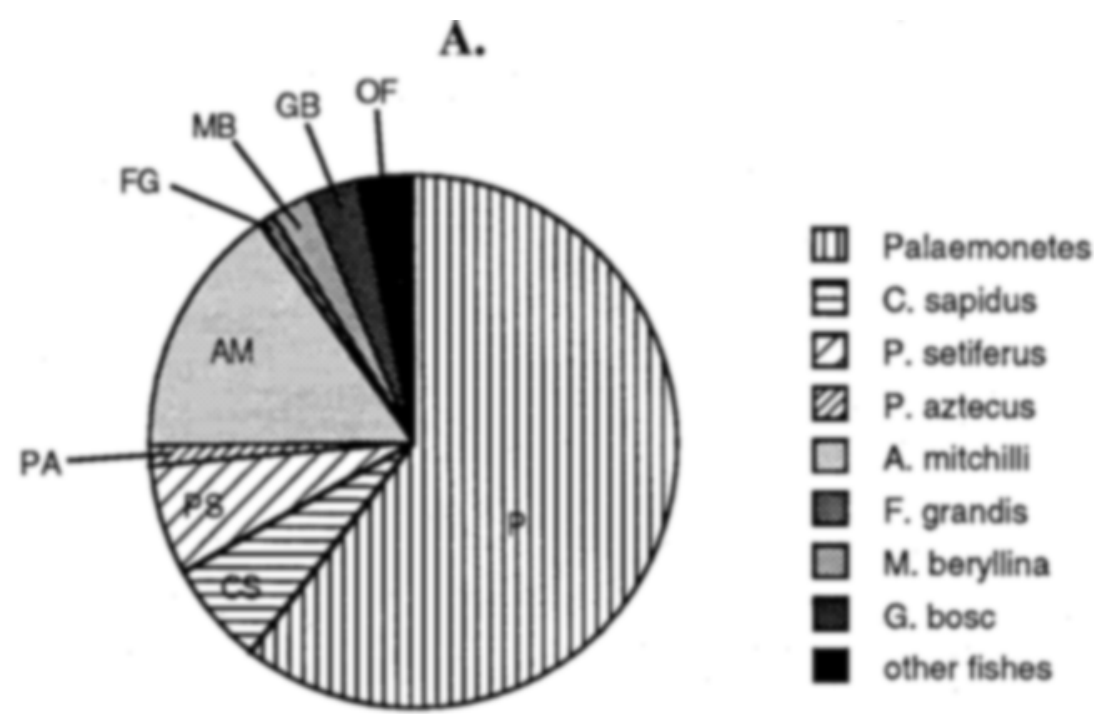

\section{SPECIES COMPOSITION BY NUMBERS}

B.

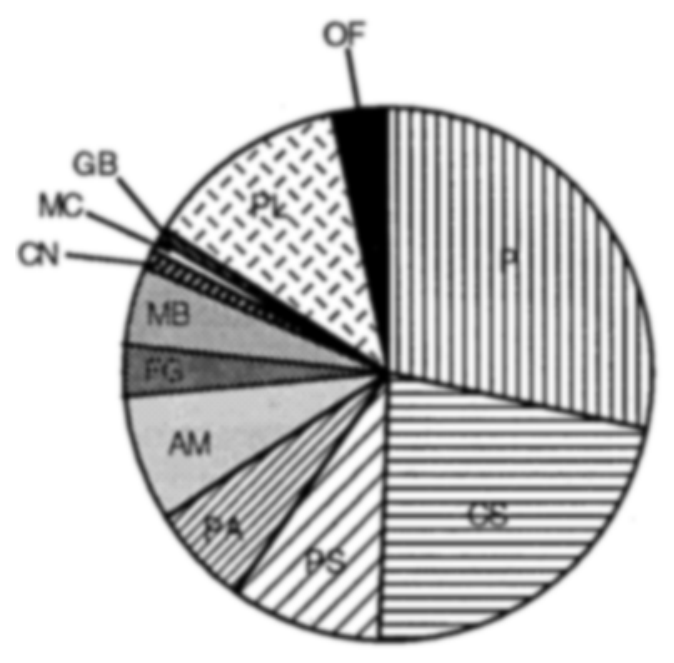

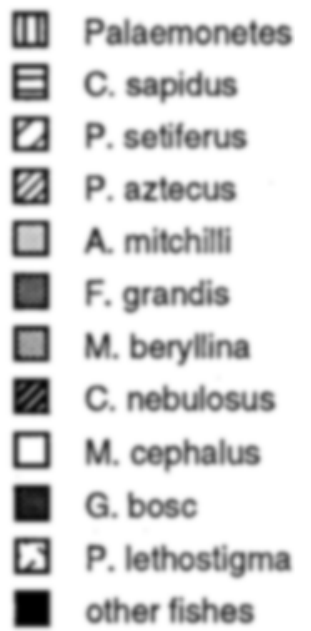

\section{SPECIES COMPOSITION BY WEIGHT}

Fig. 4. Pie charts illustrating the proportion of total flume net catch represented by the most abundant fish and decapod species. A. Species composition by numbers. B. Species composition by wet weight.

bers $(F=162.90, p<0.0001)$ in front nets than in back nets. The transicnt fish species were much less abundant in flume catches. These species made up $6 \%$, of the total fish number and $49 \%$ of the total fish biomass, and were caught exclusively in the front nets.

Only eight specics of fish were caught in back nets and all belonged to the order Cyprinodonti- formes (families Cyprinodontidae and Poecilidae), except for one Menidia beryllina (Table 4). Five of these eight species (Fundulus pulvereus, Gambusia affinis, Poecilia latipinna, Adinia xenica, and Cyprinodon variegatus) were more abundant in the back nets than in the front nets. Two other Cyprinodontid species (Lucania parva and Fundulus grandis) were commonly caught in back nets but were 
TABIF. 3. Number and percent of each decapod species caught in front and back nets, and total number caught in flume net collections from January through November 1989 from only those tlumes (10, 20, and $40 \mathrm{~m}$ ) with front and back nets. Species are listed in order of decreasing numerical abundance.

\begin{tabular}{|c|c|c|c|c|c|c|}
\hline \multirow[b]{2}{*}{ Taxa } & \multicolumn{2}{|c|}{ Front Nets } & \multicolumn{2}{|c|}{ Back Nits } & \multicolumn{2}{|c|}{ Toral } \\
\hline & Number & Percent & Number. & Percent & Number & Percent" \\
\hline Palcemonetes sp. & 17,665 & 98.9 & 196 & 1.1 & 17,861 & 83.4 \\
\hline Callinectes sapidus & 2.102 & 90.9 & 211 & 9.1 & 2.313 & 10.8 \\
\hline Uca sp. & 1 & 0.1 & 802 & 99.9 & 803 & 3.8 \\
\hline Penaeus setiferus & 143 & 100.0 & 0 & 0.0 & 143 & 0.7 \\
\hline Penaeus aztecus & 1.33 & 100.0 & 0 & 0.0 & 133 & 0.6 \\
\hline Xanthidae (fam.) & 126 & 100.0 & 0 & 0.0 & 126 & 0.6 \\
\hline Sesarma sp. & 17 & 60.7 & 11 & 39.3 & 28 & 0.1 \\
\hline Macrobrachium ohione & 1 & 100.0 & 0 & 0.0 & 1 & 0.0 \\
\hline Paguridea (fam.) & 1 & 100.0 & 0 & 0.0 & 1 & 0.0 \\
\hline Total decapods & 20,189 & 94.3 & 1,220 & 5.7 & 21,409 & 100.0 \\
\hline
\end{tabular}

"Percentage of that species caught in front or back nets.

"Percentage of total decapods (caught in $10-\mathrm{m}, 20-\mathrm{m}$, and 40 -m flumes only) represented by that species.

more abundant in front nets. The saltmarsh topminnow (Fundulus jenkinsi) was the only Cyprinodontid species that was never caught in a back net. All other fish species, including a few estuarine residents (primarily Gobiids) and all transient fish species, were caught exclusively in the front nets ('Table 4).

\section{Block Effect}

The experiment was set up in a randomizedblock design with three adjacent blocks (REP) of flume-length treatments (FLENG $\Gamma \mathrm{H}$ ). Microhabitat differences among the three treatment blocks may have led to the occasional differences among adjacent blocks. In general, REP A (the northernmost block) produced higher total catches of fish and decapods than REPs $C$. and $B$. On a specics level, this same trend was apparent for Gobiosoma bosc and Palaemonetes sp., the most abundant fish and decapod species. These differences may have been due to slight differences in elevation profiles in the marsh; however, these elevation differences averaged less than $5 \mathrm{~cm}$ (Fig. 3B) and are highly variable, with no clear trends by block. The adjacent creek (0-5 $\mathrm{m}$ from the edge) had a slightly steeper bottom profile and a small oyster recf in front of flumes 3 and 4 (REP A). This reef could have had some unknown effect on organisms using the adjacent marsh. In contrast, three species that were commonly caught in back nets (Cyprinodon variegatus, Adinia xenica, and Lucania parva) were significantly more abundant in REP C than in othcr blocks. The other three species that were commonly caught in back nets (Fundulus grandis, $F$. pulvereus, and Poecilia latipinna) were also most abundant in REP $C$ but not significantly so. The higher catch of Cyprinodontid species in REP C is probably an effect of several muskrat trails close to the back openings of flumes 14 and 15 (REP C).
These muskrat trails provided access and refuge to marsh-resident species.

\section{Date Effect}

The variable DATE was included in all ANOVA models to remove the expected source of variation caused by seasonal differences in species abundance. In almost all cases this DATE effect was found to be highly significant $(p<0.01)$. These scasonal differences in species abundance may result from the migration of species in and out of marsh areas, or from changes in behavior with seasonal changes in hydrology (depth of flooding), temperature, or salinity.

\section{Comparisons of Flume Length Treatments}

The total catch of each species by flume length (treatment) is listed in Table 5. The total catch of fish and decapods (front and back nets combined) varicd significantly between treatments. Similar results were found only for decapods since decapods dominate the total catch. In both cases, significantly higher mean numbers were caught in the 40-m flumes than in other flume lengths. The next highest catches were in the $10-\mathrm{m}$ flumes followed by the no-flume treatmont $(0 \mathrm{~m})$, the 20 -m flume treatment, and the 3-m flume treatment; however, these four treatments were not significantly different from each other. When catches in the long flumes $(10 \mathrm{~m}, 20 \mathrm{~m}$, and $40 \mathrm{~m}$; pooled) and short flumes $(3 \mathrm{~m})$ were compared, the long flume catches were significantly higher for total fish and decapods and for decapods only (Fig. 5). These results indicate use of the interior marshes by some fish and decapods.

When the catches of fish only were compared, the differences betwcen treatments were also significant. Catches from the 40-m, 10-m, and 20-m flumes were greater than catches from the 3-m and 
TABI.F. 4. Number and percent of each fish species caught in front and back nets, and total number caught in flume net collections from January through November 1989 from only those flumes $(10,20$, and $40 \mathrm{~m})$ with front and back nets. Species are listed in order of decreasing numerical alundance.

\begin{tabular}{|c|c|c|c|c|c|c|c|}
\hline \multirow[b]{2}{*}{ tish Species } & \multirow{2}{*}{$\begin{array}{l}\text { Fcological" } \\
\text { C. lassification }\end{array}$} & \multicolumn{2}{|c|}{ Front Nets } & \multicolumn{2}{|c|}{ Back Nets } & \multicolumn{2}{|c|}{ Total } \\
\hline & & Number & Percent" & Cumber & Peicent" & Number & Percont: \\
\hline Gobiosoma bosc & $\mathbf{R}$ & 968 & 100.0 & 0 & 0.0 & 968 & 33.3 \\
\hline Fundulus grandis & $\mathbf{R}$ & 455 & 90.8 & 46 & 9.2 & 501 & 17.2 \\
\hline Adinia xenica & $\mathbf{R}$ & 74 & 20.2 & 293 & 79.8 & 367 & 12.6 \\
\hline Fundulus pulvereus & $\mathbf{R}$ & 15 & 4.8 & 298 & 95.2 & 313 & 10.8 \\
\hline Poecilia latipinna & $\mathrm{R}$ & 21 & 12.5 & 147 & 87.5 & 168 & 5.8 \\
\hline I.ucania parua & $\mathbf{R}$ & 68 & 61.3 & 13 & 38.7 & 111 & 3.8 \\
\hline Gyprinodon variegatus & $\mathbf{R}$ & 30 & 28.0 & 77 & 72.0 & 107 & 3.7 \\
\hline Cobionellus boleosoma & $\mathbf{R}$ & 90 & 100.0 & 0 & 0.0 & 90 & 3.1 \\
\hline I'undulus jenkinsi & $\mathbf{R}$ & 66 & 100.0 & () & 0.0 & 66 & 2.3 \\
\hline Menidia beryllina & $\mathbf{R}$ & 52 & 98.1 & 1 & 1.9 & 53 & 1.8 \\
\hline Gynoscion nelulosus & $\mathrm{I}$ & 43 & 100.0 & 0 & 0.0 & 43 & 1.5 \\
\hline Mugril cephalus & $\mathrm{I}$ & 41 & 100.0 & () & 0.0 & 41 & 1.4 \\
\hline Mrophis penctatus & $\mathrm{l}$ & 17 & 100.0 & 0 & 0.0 & 17 & 0.6 \\
\hline Archosargus probatocephalus & $\mathrm{I}$ & 12 & 100.0 & 0 & 0.0 & 12 & 0.4 \\
\hline Anchoa mitchilli & $\mathbf{I}$ & 9 & 100.0 & 0 & 0.0 & 9 & 0.3 \\
\hline Gambusia affinis & $\mathrm{R}$ & 1 & 11.1 & 8 & 88.9 & 9 & 0.3 \\
\hline Bairdiella chnsoura & $\mathrm{T}$ & 8 & 100.0 & 0 & 0.0 & 8 & 0.3 \\
\hline Achirus lineatus & $\mathrm{T}$ & 5 & 100.0 & 0 & 0.0 & 5 & 0.2 \\
\hline Micropogonias undulatus & $\mathrm{I}$ & 3 & 100.0 & 0 & 0.0 & 3 & 0.1 \\
\hline lagodon rhomboides & $\mathrm{R}$ & 3 & 100.0 & 0 & 0.0 & 3 & 0.1 \\
\hline Gobionellus shufeldii & $\mathrm{R}$ & 3 & 100.0 & 0 & 0.0 & 3 & 0.1 \\
\hline Citharichthys spilopterus & $\mathrm{T}$ & 3 & 100.0 & 0 & 0.0 & 3 & 0.1 \\
\hline Symphumes plagiusa & $\mathrm{T}$ & 3 & 100.0 & 0 & 0.0 & 3 & 0.1 \\
\hline Gynoscion arenarius & 1 & 1 & 100.0 & 0 & 0.0 & 1 & 0.0 \\
\hline Sciaenops orellatus & 1 & 1 & 100.0 & 0 & 0.0 & 1 & 0.0 \\
\hline Syngnathus floridae & $\mathrm{I}^{\circ}$ & 1 & 100.0 & 0 & 0.0 & 1 & 0.0 \\
\hline Opsanus beta & $\mathrm{T}$ & 1 & 100.0 & 0 & 0.0 & 1 & 0.0 \\
\hline Total resident fish & $\mathrm{R}$ & 1,846 & 66.9 & 913 & 3.3 .1 & 2,759 & 94.9 \\
\hline lotal transient fish & $\mathrm{I}$ & 148 & 100.0 & 0 & 0.0 & 148 & 5.1 \\
\hline Total fish & & 1,994 & 68.6 & 913 & 31.4 & 2,907 & 100.0 \\
\hline
\end{tabular}

"Ecological classification: $\mathrm{R}=$ resident; $\mathrm{T}$ = transient.

bercentage of that species caught in tront or back nets.

'Percentage of total fish (caught in 10-m, 20-1m, and 40-m flumes only) represented by that species.

0 -m flumes. The apparent trend of lower fish catches in the shorter flumes to higher catches in the longer flumes indicates some use of the interior marshes by fishes. ANOVA test results for marsh-resident fish showed significant differences in catches between treatments with higher catches in long flumes when contrasted with short flumes (Fig. 6). Transient fish showed no differences in catch between treatments or between long and short flumes (Fig. 7), indicating that transient fish are not using the intcrior marsh habitats.

Effectiveness of No-Flume Treatment. There were no significant differences in decapod catches between the no-flume treatment and the flumes (all lengths were pooled) suggesting that the nets without flumes were just as effective at catching these organisms as those with flumes. However, fish (resident and transient) were caught in significantly higher numbers in nets with flumes (all lengths were pooled) than in the no-flume treatment., indicating a possiblc avoidance of nets with- out flumes. These generalizations did not always hold when individual species were tested.

Species Differences in Catch by Flume Length. Because habitat-use patterns vary between species, it is illustrative to analyze the data at a species level. This was done for the 20 most abundant species (13 fish, 7 decapod) caught in the flumes (species total catch $>30)$. A Bonferonni-adjusted alpha levcl $(p<0.0025)$ was used to reduce the probability of finding a significant result by chance alone. Because the Bonferroni adjustment is extremely conservative, a few species ANOVAs had significant results at $p<0.01$, which were not significant with the Bonferroni-adjusted alpha level. These cases are reported as such, because there may be some biological significance that may be overlooked using such a conservative approach.

Of the 20 species tested, only four fish species (C. variegatus, $F$ grandis, $F$. pulvereus, and $P$. latipin$n a)$ and two decapod species (Palaemonetes sp. and $U c a \mathrm{sp}$.) were found to have significantly greater 
TABLE 5. Total number of each species (fish and decapods) caught by flume length treatment (total for thee flumes) from January through November 1989. Species listed in order of decreasing numerical abundance.

\begin{tabular}{|c|c|c|c|c|c|c|}
\hline \multirow[b]{2}{*}{ Species } & \multicolumn{5}{|c|}{ Flume length treatunent } & \multirow[b]{2}{*}{ Total } \\
\hline & No Flume & $3-1 \mathrm{~m}$ & $10-\mathrm{mm}$ & $20 \mathrm{~m}$ & $40-m$ & \\
\hline Palaemonetes sp. & 5,608 & 4,752 & 5,429 & 4,852 & 7,580 & 28,221 \\
\hline Callinectes sapidus & $75 \mathrm{l}$ & 650 & 679 & 687 & 947 & 3,714 \\
\hline Gobiosoma bose & 344 & 337 & 314 & 229 & 425 & 1,649 \\
\hline Vtra sp. & 0 & 1 & 240 & 233 & 330 & 804 \\
\hline Fundulus grandis & 103 & 59 & 160 & 178 & 163 & 663 \\
\hline Adinia xenica & (i & 77 & 143 & 148 & 76 & 450 \\
\hline Fundulus pulverens & 5 & 18 & 118 & 133 & 62 & 336 \\
\hline Percueus setiforus & 123 & 41 & 62 & 42 & 39 & 307 \\
\hline Penaeus aztecus & 38 & 81 & 42 & 39 & 52 & 252 \\
\hline Xanthidae (fam.) & 51 & 30 & 48 & 22 & 56 & 207 \\
\hline Colbionellus boleosoma & 38 & 43 & 36 & 26 & 28 & 171 \\
\hline Poerilia latipinna & 0 & 1 & 29 & 96 & 43 & 169 \\
\hline I.urania parua & $s$ & 13 & 19 & 55 & 37 & 132 \\
\hline Cyprinodon variegatus & 3 & 6 & 7 & 61 & 39 & 116 \\
\hline Fundulus jenkinsi & 20 & 16 & 19 & 19 & 28 & 102 \\
\hline Menidia beryllina & 3 & 11 & 8 & 18 & 32 & 67 \\
\hline Crnoscion nebulosus & 9 & 12 & 12 & 14 & 17 & 64 \\
\hline Mugil cophalus & 2 & 4 & 8 & 20 & 13 & 47 \\
\hline Anchoa mitchilli & 1 & 29 & 2 & 3 & 4 & 39 \\
\hline Sesarma sp. & 0 & 7 & 8 & 16 & 4 & 35 \\
\hline Myrophis punctatus & 7 & 3 & 5 & 4 & 8 & 27 \\
\hline Bairdiella chrysoura & 7 & 5 & 0 & 1 & 7 & 20 \\
\hline Archosargus probatocephalus & () & is & 4 & 3 & 5 & 18 \\
\hline Cambusia affinis & 0 & 0 & 2 & 2 & 5 & 9 \\
\hline Citharichthys spiloptemes & 0 & 6 & 1 & 2 & 0 & 9 \\
\hline Achinus lineatus & 3 & l & 2 & 1 & 2 & 9 \\
\hline Micropogonias undulatus & 1 & 2 & 2 & 0 & 1 & 6 \\
\hline Lagodon rhomboides & 0 & 2 & 0 & 0 & 3 & 5 \\
\hline Gobionellus shufeldti & 0 & 1 & 0 & 3 & 0 & 4 \\
\hline Symphurus plagiusa & 1 & () & 1 & 2 & 0 & 1 \\
\hline Sciaenops ocellatus & 2 & 0 & 0 & 1 & 0 & 3 \\
\hline Macrobrachium ohione & 1 & 0 & ) & 1 & 0 & 2 \\
\hline Cynoscion arenarius & 0 & 0 & 1 & 0 & 0 & 1 \\
\hline Syngnathus floridae & 0 & () & 0 & 0 & 1 & 1 \\
\hline Singnathus scovelli & 1 & 0 & 0 & 0 & 0 & 1 \\
\hline Paralichthys lethostigma & 0 & 1 & 0 & 0 & 0 & 1 \\
\hline Opsarues beta & 0 & 0 & 0 & 1 & 0 & 1 \\
\hline Paguridea (fam.) & 0 & 0 & 0 & 1 & 0 & i \\
\hline Total resident fish & 531 & 584 & 855 & 963 & 941 & 3,874 \\
\hline Total transient fish & 33 & 69 & 38 & 52 & 58 & 250 \\
\hline Total fish & 564 & 65.3 & 893 & 1,015 & 999 & 4,124 \\
\hline Total decapods & 6,572 & 5,562 & 6.508 & 5,893 & 9,008 & 33,543 \\
\hline Total fish and decapods & 7,136 & 6.215 & 7,401 & 6,908 & 10,007 & 37,667 \\
\hline
\end{tabular}

catches in the long flumes when contrasted with the 3-m flumes, indicating a significant use of interior marshes by these species. The four fish species are all resident Cyprinodontiform species. Two other Cyprinodontid specics, $I$. parva and $A$. xeni$c a$, were not significantly more abundant in long flumes when contrasted with short flumes. However, both species were commonly caught in the back nets (Table 4), thereby documenting the frequent use of interior marshes by these species as well.

All other abundant fish species (total catch $>30$ ) that were tested with ANOVA were found to have no significant differences between catches from long vs short flumes. These included four resident species ( $F$. jenkinsi, $G$. bosc, $G$. boleosoma, and $M$. beryllina) and three transient species ( $C$. nebulosus, $M$. cephalus, and $A$. mitchilli). Three of these species, A. mitchilli $(\mathrm{p}=0.11)$, M. beryllina $(\mathrm{p}=0.23)$, and $M$. cephalus $(p=0.40)$, had nonsignificant ANOVA models (REP, DATF., FLENGTH), probably because of the low numbers caught. The relative abundance of these seven fish species in flume catches indicates that the marsh surface may be utilized by these fish at high tide; however, the uniformity of catches among flumes of different lengths and the absence of these species from back nets (except for one individual of $M$. beryllina 
A.
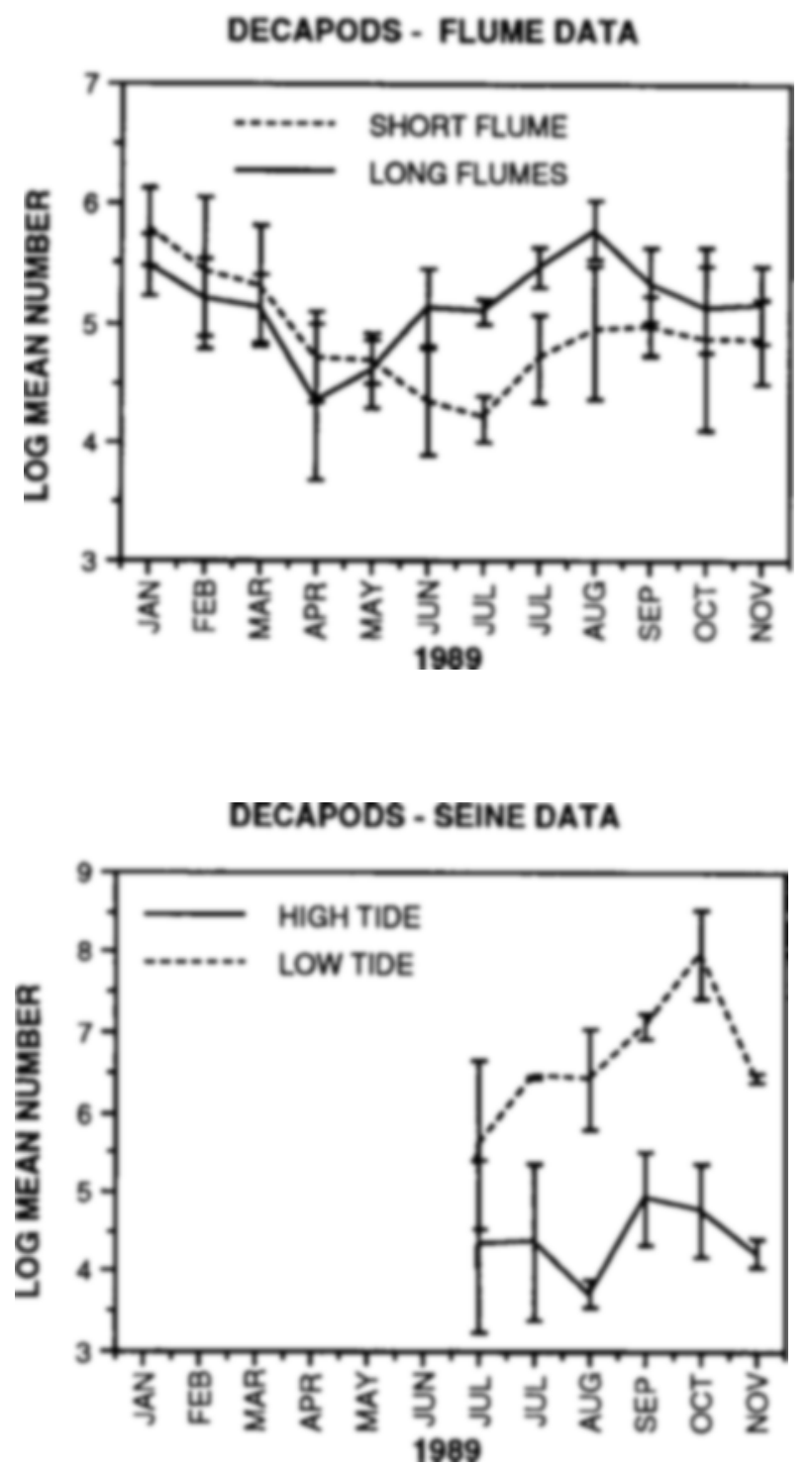

Fig. 5. The log mean numbers of decapods caught by sample date. A. In short flumes $(3 \mathrm{~m})$ vs long flumes $(10-\mathrm{m}, 20-\mathrm{m}$, and $40-\mathrm{m}$ flumes). B. At low and high tide with seines. The vertical bars represent one standard error of the mean.

caught in a 40-m back net) indicates that these species mostly use the edge marshes $(<3 \mathrm{~m})$ or possibly only the adjacent creck-edge habitat.

Palaemonetes sp. and $U / c a$ sp. were significantly more abundant in long flumes than short flumes among the decapod species tested; however, the proportions of each caught in front nets ws back nets (lable 3) suggests completely different patterns of interior marsh usc. Grapsid crabs (Sesarma sp.) were caught in back nets, but there were no significant differences in catches between long and
A.
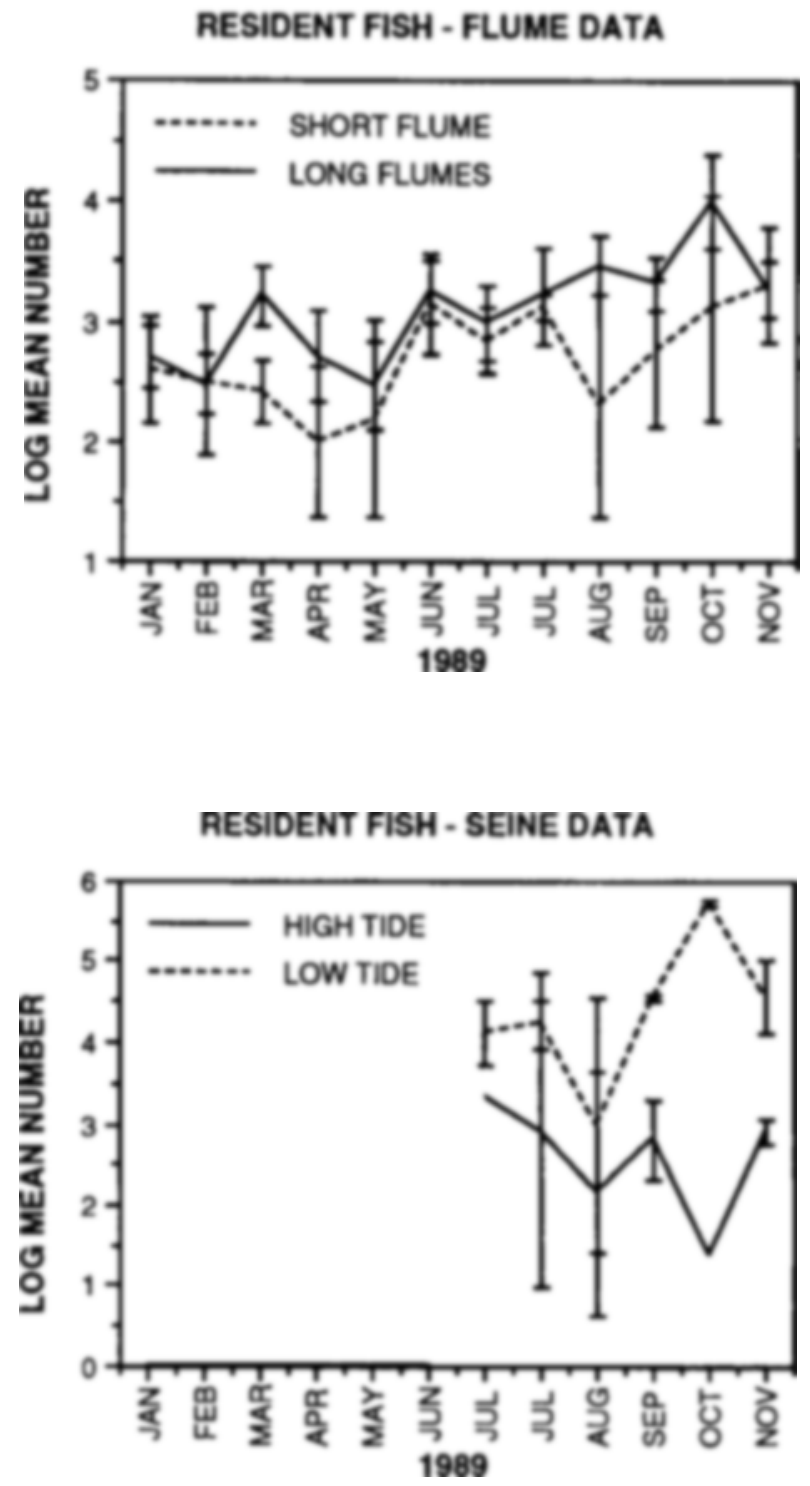

Fig. 6. The log mean numbers of resident fish caught by sample date. $A$. In short flumes ( $3 \mathrm{~m}$ ) vs long flumes (10-m, 20m, and 40-m flumes). B. At low and high tide with scines. The vertical bars represent one standard error of the mean.

short flumes or between front and back nets. Bluc crabs (Callinectes sapidus) were significantly more abundant in $40-\mathrm{m}$ flumes than in all other flume lengths; however, catches were not significantly different when long flumes $(10 \mathrm{~m}, 20 \mathrm{~m}$, and $40 \mathrm{~m})$ were contrasted with 3-m flumes for log-transformed numbers $(p=0.14)$. Blue crabs were commonly caught in back nets (Table 3 ), especially as small juveniles, documenting that blue crabs do utilize interior marshes.

Penaeid shrimp and Xanthid crabs were also 


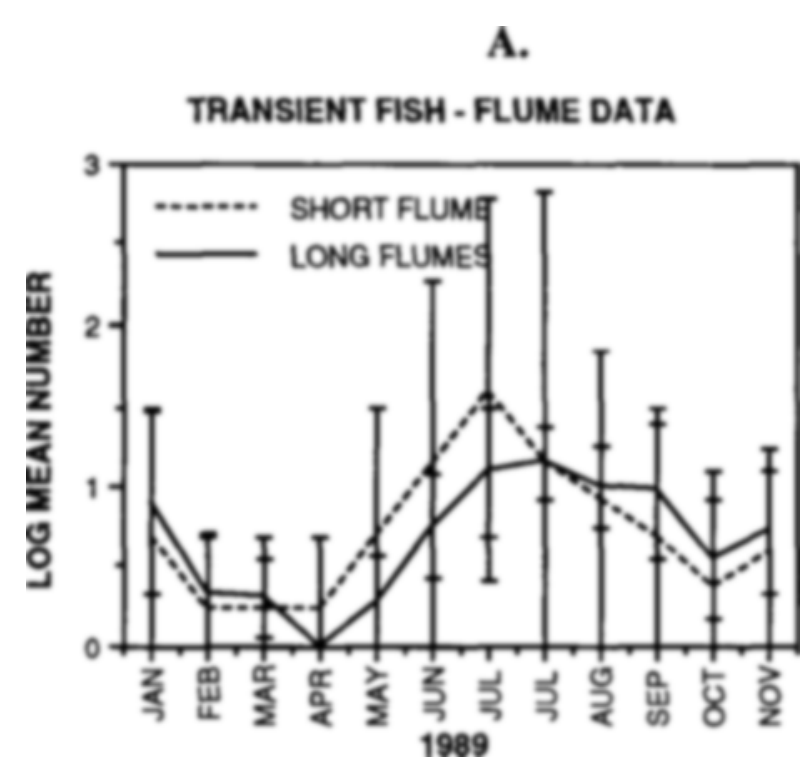

B.

TRANSIENT FISH - SEINE DATA

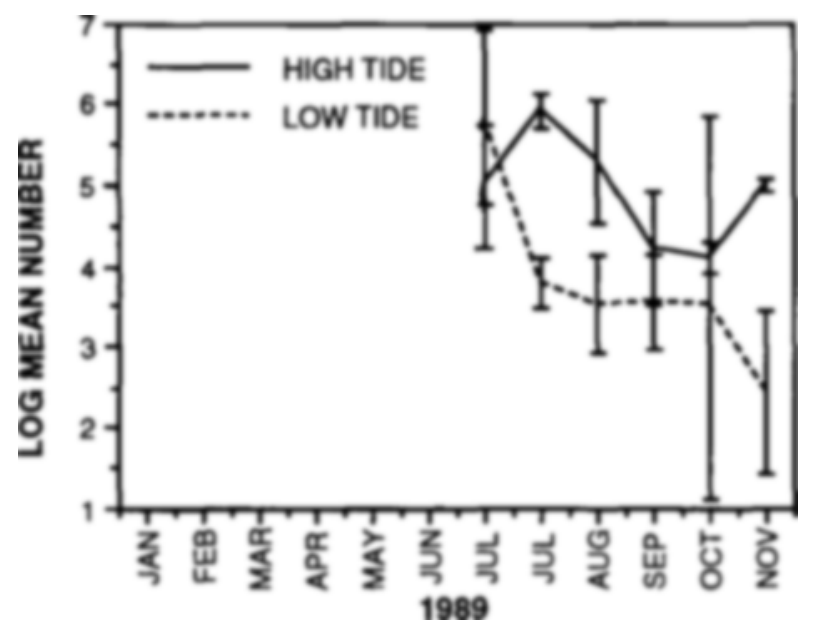

Fig. 7. The log mean numbers of transient fish caught by sample date. $\Lambda$. In short flumes $(3 \mathrm{~m})$ vs long flumes $(10-\mathrm{m}, 20$ $\mathrm{m}$, and 40-m flumes). B. At low and high tide with seines. The vertical bars represent one standard error of the mean.

abundant in flume net samples, but the data suggests that their use of the marsh is restricted to the edge marshes ( $<3 \mathrm{~m}$ from creek). ANOVA test rcsults show no differences between long and short flumes for Xanthid crabs and Penaeus setiferus. Penaeus aztecus was significantly $(\mathrm{p}=0.008)$ more abundant in 3-m flumes than in long flumes, but this difference is not significant with the Bonferroni-adjusted alpha level $(p=0.0025)$. None of these three species were ever caught in back nets (Table 3).
All other fish and decapod species, most of which were transient species, were not caught in sufficient numbers to test with ANOVA. This in itself is an indication that these species are infrequently or rarely using the marsh-surface habitat. The relative abundance of some of these species in seine samples suggests that they are prescnt in the area but not using the marsh surface. One exception may be Gambusia affinis, a mostly freshwater marsh resident that was caught infrequently but almost exclusively in back nets, suggesting it may use interior marshes in areas where it is more abundant.

\section{SFINE DATA \\ Species Composition}

A total of 18,539 organisms (fish and decapod crustaceans) with a total preserved wet weight of $7.1 \mathrm{~kg}$ were collected in the seine samples from July through November 1989 (Table 6). The total catch included 29 species of fish $(4,699$ individuals, $2.4 \mathrm{~kg}$ preserved wet weight) representing $16 \mathrm{fam}$ ilies and at least 7 species of decapod crustaccans $(13,840$ individuals, $4.7 \mathrm{~kg}$ preserved wet weight). The number of fish species caught in flumes and scines was the same (29), but the species composition was different because of the different habitats sampled by each gear and scasonal differences in sampling (scine samples were only collccted from July to November).

The total seine catch was dominated by decapod crustaceans, which made up $74.6 \%$ of the total number and $65.8 \%$ of the total biomass (Table 6 and Fig. 8). Grass shrimp (Palaemonetes sp.), the dominant species in the flume net experiments, dominated the seine catches, comprising $60.4 \%$ by number and $28.4 \%$ by biomass. Other decapods that were abundant in scine samples include the Penaeid shrimp and bluc crabs.

Compared with flume catch data, fish species made up a larger proportion of the total seine catch $(25.3 \%$ by number, $23.6 \%$ biomass), and were dominated by bay anchovy (Anchoa mitchilli), which represented $15.6 \%$ of the total catch by numbers $(7.7 \%$ of biomass). Naked goby (Gobiosoma bosc) was the next most abundant fish species caught $(3.0 \%$ of total), followed by tidewater silversides (Menidia beryllina). A single specimen of southern flounder (Paralichthys lethostigma) represented more biomass $(12.5 \%$ of total) than all 2,901 bay anchovies, the most abundant fish in seine samples.

\section{High Tide us Low Tide}

The total catch (log-transformed) was significantly higher in low-tide seine samples than hightide seine samples. This same relationship (low > 
high tide) held true for decapods only and resident fish only (Figs. 5 and 6 ). This provides supporting evidence that these organisms arc using the marsh surface at high tide and returning to the creek at low tide. In contrast, transient fish were significantly more abundant in high-tide samples (Fig. 7). This pattern could result from fish moving from deeper water to the marsh edge at high tide. Differences in fish species abundance were apparent among seine samples collected from July through November. When the total fish catch was tested with ANOVA, there was no difference in catch between high and low tide samples; however, a shift in fish abundance between low-tide and high-tide samples with season resulted in a significant DATE-TIDE interaction. This interaction resulted primarily from the abundance of Anchoa mitchilli in high tide samples in July and August and the abundance of Gobiosoma bosc and Fundulus grandis in low tide samples in October.

Species Differences in Catch by Tide Stage. Bccause habitat-use patterns vary between species, the seine catch data were analyzed with ANOVA for the 14 most abundant species (10 fish and 4 decapod species with total catches $>30$ ). Again, as with the flume data analysis, a Bonferroni-adjusted alpha level $(p<0.0036)$ was used to reduce the problem of finding a significant result by chance alone. Of the 14 species tested, four fish species (G. bosc, F. grandis, G. boleosoma, and L. parra) and two decapod species (Palaemonetes sp. and C. sapidus) were significantly more abundant in low-tide samples when compared to high-tide samples. Two other fish species, C. nebulosus and $M$. beryllina, were more abundant in low tide samples $(p=$ 0.018 ), but this difference was not significant with the more conservative Bonferroni alpha level $(p<$ $0.0036)$. This pattern of higher abundance in lowtide scine samples, combined with the relative abundance of these eight species in flume samples, is strong evidence that these species use the marshsurface habitat (at least at the edge) when it is flooded.

The total catch of Penaens azterus from low-tide samples was approximately double that from hightide samples (Table 6), but this difference was not statistically significant $(p=0.08)$ with log-transformed catch data. White shrimp (Penaeus setiferus) were not significantly more abundant in low-tide than in high-tide samples. Both penacid species were commonly caught in flume nets.

Twice as many Achirus lineatus were caught in low-tide samples as in high-tide samples, but this difference was not significant $(p=0.11)$. Another flatfish, Symphurus plagiusa, was equally abundant in high-tide and low-tide seine samples. Both of these species were rarely caught in flume nets.
TABI.E 6 . List of species collected from seine samples along edge from July through November 1989 in order of decreasing numerical abundance. Number caught at high tide and low tide, and total number and percentage of total catch are given for each species.

\begin{tabular}{|c|c|c|c|c|}
\hline Species & $\begin{array}{l}\text { High } \\
\text { Tikite }\end{array}$ & Low Tide & Total & Percent \\
\hline Paluemonetes sp. $(\mathrm{R})^{\mathrm{b}}$ & 304 & 10,893 & 11,197 & 60.40 \\
\hline Anchoa mitchilli $(\mathrm{T})$ & 1,904 & 997 & 2,901 & 15.65 \\
\hline Pencuess setiferus (T) & 526 & 701 & 1,227 & 6.62 \\
\hline Callinectes sapidus (T) & 187 & 994 & 1,181 & 6.37 \\
\hline Gobrosoma bosc $(\mathbf{R})$ & 41 & 524 & 565 & 3.05 \\
\hline Menidia beryllina $(\mathbf{R})$ & 130 & 329 & 459 & 2.48 \\
\hline Penaeus aztecus ( $\mathrm{T}$ ) & 71 & 144 & 215 & 1.16 \\
\hline Fundulus grandis $(\mathrm{R})$ & 0 & 160 & 160 & 0.86 \\
\hline Gobionellus boleosoma $(\mathrm{R})$ & 20 & 128 & 148 & 0.80 \\
\hline Lucania parva $(\mathrm{R})$ & 0 & 125 & 125 & 0.67 \\
\hline Symphurus plagiusa (T) & 38 & 36 & 74 & 0.40 \\
\hline Achimes lineatus (I) & 20 & 40 & 60 & 0.32 \\
\hline Cynoscion nebulosus (T) & 8 & 33 & 41 & 0.22 \\
\hline Brezoortia patronus (1") & 24 & 13 & 37 & 0.20 \\
\hline Fundulus jenkinsi (R) & l & 23 & 24 & 0.13 \\
\hline Cynoscion arenarius $(\mathrm{T})$ & 11 & 11 & 22 & 0.12 \\
\hline Micropogonias undulatus $(\mathrm{T})$ & 17 & 4 & 21 & 0.11 \\
\hline Bairdiella chrysoura (T) & 13 & 7 & 20 & 0.11 \\
\hline Xanthidae (R) & I & 16 & 17 & 0.09 \\
\hline Citharichthys spilopterus $(\mathrm{T})$ & 6 & 7 & 13 & 0.07 \\
\hline Membras martinira $(\mathrm{R})$ & 7 & 0 & 7 & 0.04 \\
\hline Mugil sephalus ( $\mathrm{T}$ ) & 3 & 1 & 4 & 0.02 \\
\hline S)ngnathus stovtelli $(\mathrm{R})$ & 0 & 3 & 3 & 0.02 \\
\hline Sciaenops ocellatus (I) & 0 & 2 & 2 & 0.01 \\
\hline Syngnathus louisianae (T) & 1 & 1 & 2 & 0.01 \\
\hline Sphoeroides partus (I) & 1 & 1 & 2 & 0.01 \\
\hline Prionolus tritrulus (I) & 1 & 1 & 2 & 0.01 \\
\hline Macrobrachium ohione $(\mathrm{R})$ & 1 & 1 & 2 & 0.01 \\
\hline P'oerilia latipinna $(\mathrm{R})$ & 0 & 1 & 1 & 0.01 \\
\hline Strongylura marina ( $\mathrm{T}$ ) & 0 & 1 & 1 & 0.01 \\
\hline Stellifer lanceolatus ( $\mathrm{I}$ ) & 1 & 0 & 1 & 0.01 \\
\hline Gobionellus shufeldti $(\mathbf{R})$ & I & 0 & 1 & $0.0 \mathrm{I}$ \\
\hline Arius felis $(\mathrm{T})$ & 1 & 0 & 1 & 0.01 \\
\hline Paralichthys lethostigma $(\Gamma)$ & 1 & 0 & 1 & 0.01 \\
\hline Microgotnus thalassinus (R) & 1 & 0 & 1 & 0.01 \\
\hline Sesarina sp. (R) & 1 & 0 & 1 & 0.01 \\
\hline Total resident individuals & 508 & 12,203 & 12,711 & 68.56 \\
\hline Total transient individuals & 2,834 & 2,994 & 5,828 & 31.44 \\
\hline Total fish and decapods & 3,342 & 15,197 & 18,539 & 100.00 \\
\hline
\end{tabular}

"Percentage of total catch represented by that species.

${ }^{b}$ Ecological classification (in parentheses): $\mathrm{R}=$ resident, $\mathrm{I}=$ transient.

Anchoa mitchilli, the most abundant fish species in seine samples, was significantly more abundant in high-tide samples. Gulf menhaden (Brevoortia patronus), another abundant filter-fecder, had slightly higher catches in high-tide seine samples (Table 6), but the differences were not significant. The relatively low numbers of menhaden caught in scines is a function of the absence of complete seasonal sampling. Catches would have been much greater if scine samples had becn collected in the winter and carly spring when postlarval and juvenile menhaden are abundant in the estuaries. 


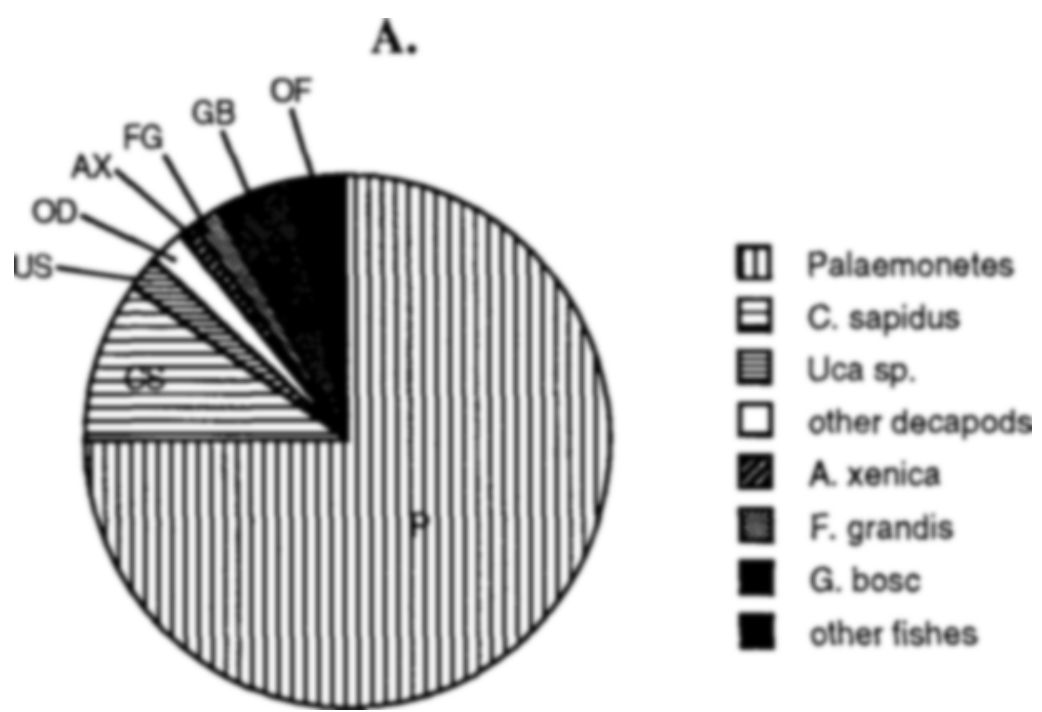

\section{SPECIES COMPOSITION BY NUMBERS}

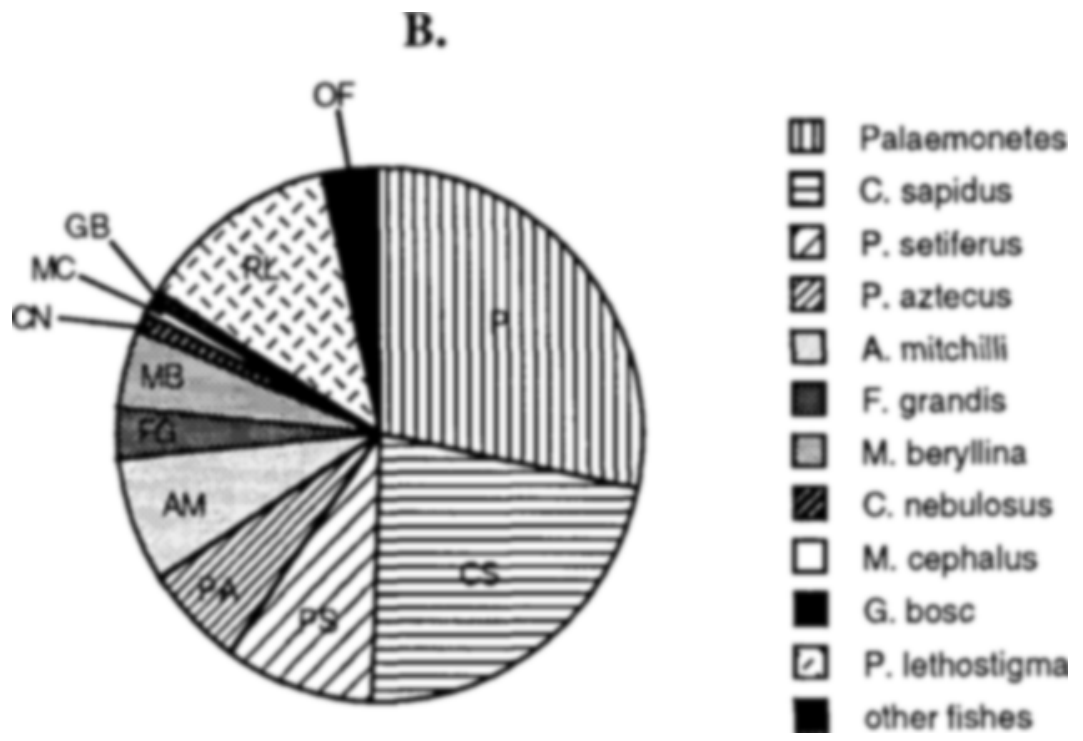

\section{SPECIES COMPOSITION BY WEIGHT}

Fig. 8. Pie charts illustrating the proportion of the total scine catch represented by the most abundant fish and decapod species. A. Species composition by numbers. B. Species composition by weight.

\section{COMBINing FILMF NFT AND SEINE DATA}

Flume and seine catch data are not quantitatively comparable because of the differences in the methods of fishing (passive vs active), the habitats sampled (marsh surface vs creek edge), and the size of the areas sampled. However, by comparing (qualitatively) the relative abundance and distribution (spatial and temporal) of species caught by these two gears, we can begin to see how marsh and edge habitats are utilized. These relationships are shown in Fig. 9. For example, several species (fish: A. xenica, $F$. pulvereus, $P$. latipinna, $C$. variegatus; decapods: Uca sp., Sesarma sp.) were rare or absent in seine samples but were abundant in flumes, especially in the back (interior) nets. These represent true marsh-resident species that forage on the flooded interior marsh and take ref- 


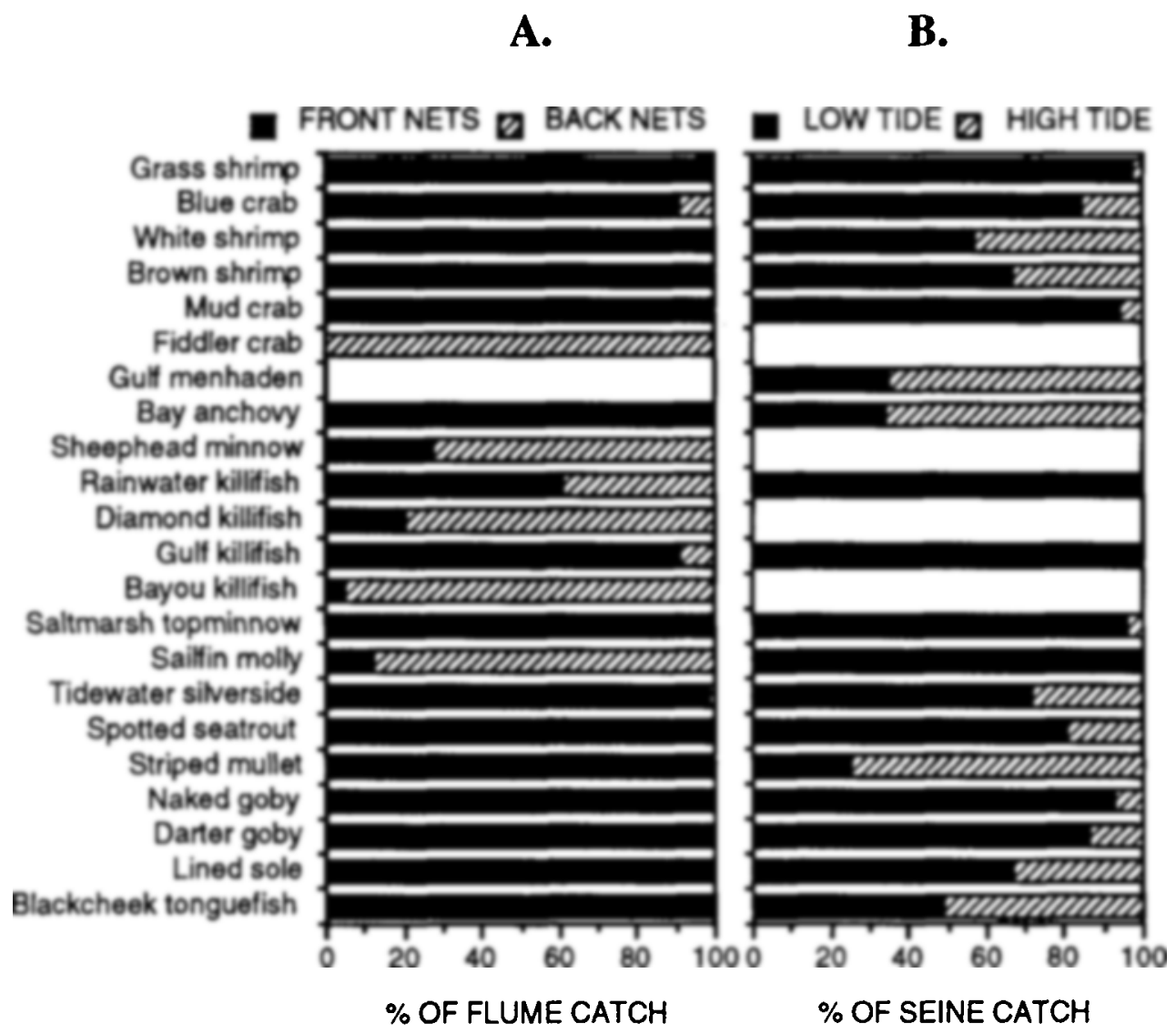

Fig. 9. Relative proportions (percent of total catch) of most abundant species caught in $\lambda$. front versus back nets of flumes and B. low versus high tide seine samples.

uge in small ponds, potholes, burrows, muskrat trails, and rivulets at low tide, and only rarely retreat to the open water of the creek. Mugil cephalus, Myrophis punctatus, and Xanthid crabs were also more abundant in flumes than in seine samples; however, this could result from their ability to avoid seines, either by burrowing in mud (worm cels and mud crabs) or by swimming fast or jumping (mullet). On the other extreme are open-water estuarine species (e.g., Anchoa mitchilli, Brevoortia patronus, Micropogonias undulatus) that were relatively common in scines, especially at high tide, but were rarely or never caught in flumes, indicating that the flooded marshes are not utilized as nurscry habitat by these species.

The catch data by gear and the results of ANOVA tests for the most abundant fish and decapod species ( $>30$ individuals with one gear) collected from flume nets and seines are summarized in Table 7 . The ANOVA results are summarized for the comparisons of (log-transformed) catches between front and back nets, and between long and short flumes for flume net data, and between high-tide and low-tide catches for scine data.

\section{Marsh Labitat L'tilization Patterns}

Not all estuarine species utilize flooded marsh habitat to the same extent. A qualitative comparison of the results given in Table 7 indicated four gencral patterns of marsh utilization. The 10 most abundant fish species captured in flume nets ( $T$ able 4) are considered resident species because they spend their entire lives within the estuary. We assigned a species to one of four general patterns of marsh habitat utilization. Figure 10 shows a typical profile of a creck edge and adjacent marsh with the area of utilization delineated for each category.

(A) Interior Marsh Residents. The first habitatuse pattern describes species that move into interior marshes whenever they are flooded and then retreat to potholes, muskrat trails or small ponds at low tides. These species probably gain access to interior marshes through small rivulets or muskrat trails and seck refuge in these low wet areas during normal low tides. These species may burrow in the mud or find their way back to the creek during extreme low-water levels. These species represent the true marsh-resident species that are adapted to 
TABLE 7. Summary of catch data and ANOVA results for the most abundant fish and decapod species collected from flume nets and seines from January through November 1989. The total catch (number) of each species is given for each gear. Results of AVOVA tests are summarized for comparisons between front and back nets (NET) and flume length treatments (FLE.VGIH) for flume data, and between tide stages (IIDE) for seine data. (only or $>$ ) = significantly greater at a Bonfcrroni adjusted alpha level ( $p<0.0025$ ); $(\geq)=$ significantly greater at $p<0.05$, but not at Bonferroni adjusted alphat level $(p<0.0025) ;(=)=$ not significantly different $(p$ $>0.05) ;(*)=$ not tested $(n<30)$.

\begin{tabular}{|c|c|c|c|c|c|c|}
\hline \multirow[b]{2}{*}{ Species } & \multicolumn{3}{|c|}{ Flume Net Datat } & \multicolumn{2}{|c|}{ Scrine Data } & \multirow{2}{*}{$\begin{array}{l}\text { Habitat lse } \\
\text { Category" }\end{array}$} \\
\hline & Number & NET & FI.FNGTI" & Number & rIDE & \\
\hline \multicolumn{7}{|l|}{ Fishes } \\
\hline Ciprinodon variegatus & 116 & $B \geq F$ & $\mathrm{~L}>\mathrm{S}$ & 0 & * & $A$ \\
\hline Adinia xenica & 450 & $\mathrm{~B}>\mathrm{F}$ & $\mathrm{I} .=\mathrm{S}$ & 0 & * & $A$ \\
\hline Fundulus pulverencs & 336 & $\mathbf{B}>\mathbf{F}$ & I. $>\mathrm{S}$ & 0 & $*$ & $\Lambda$ \\
\hline Poecilia latifinna & 169 & $\mathrm{~B}>\mathrm{F}$ & $\mathrm{L}>\mathrm{S}$ & 1 & L only* & $\mathrm{A}$ \\
\hline Lucania parva & 132 & $F=B$ & $\mathrm{I}, \because \mathrm{S}$ & 125 & I. only & B \\
\hline Fundulus grandis & 663 & $F=B$ & L. $>\mathrm{S}$ & 160 & I. only & B \\
\hline Fundulus jenkinsi & 102 & F only & $\mathbf{I} .=\mathbf{S}$ & 24 & I. $>\mathrm{H}^{*}$ & C \\
\hline Menidia beryllina & 67 & $\mathrm{~F}>\mathrm{B}$ & I. $=\mathrm{S}$ & 459 & I. $\geq \mathrm{H}$ & C \\
\hline Cjnoscion nebulosus & 64 & F only & $\mathrm{I} .=\mathrm{S}$ & 41 & $\mathrm{I}, \geq \mathrm{H}$ & C: \\
\hline Mugil cephalus & 47 & $\mathrm{~F}$ only & $\mathrm{L} .=\mathrm{S}$ & 4 & $*$ & $C$ \\
\hline Gobrosoma bosc & 1,649 & F only & $\mathrm{I},=\mathrm{S}$ & 565 & $\mathrm{I} .>\mathrm{H}$ & C \\
\hline Gobionellus boleosoma & 171 & F only & I. $\because S$ & 148 & $\mathrm{I} .>\mathrm{H}$ & C: \\
\hline Achimus lineatus & 9 & F only* & $*$ & 60 & $\mathrm{H}-\mathrm{I}$ & D \\
\hline Symphurus plagiusa & 4 & F only* & $*$ & 74 & $\mathrm{H}=\mathrm{I}$ & D) \\
\hline Anchoa mitchilli & 39 & F only & 1. $=\mathrm{S}$ & 2,901 & $\mathrm{H}>\mathrm{I}$ & $D$ \\
\hline Brevoortia patronus & 0 & $*$ & $*$ & 37 & $\mathrm{H}=\mathrm{L}$ & D) \\
\hline \multicolumn{7}{|l|}{ Decapod crustaceans } \\
\hline Uca sp. & 804 & $\mathrm{~B}>\mathrm{F}$ & I. $>S$ & 0 & $*$ & A \\
\hline Sesarma sp. & 35 & $F=B$ & $\mathrm{I},=\mathrm{S}$ & 1 & $*$ & A \\
\hline Palaemonetes sp. & 28,221 & $F>B$ & I. $>\mathrm{S}$ & 11,197 & $\mathrm{~L}>\mathrm{II}$ & B \\
\hline Callinectes sapidus & 3,714 & $\mathrm{~F}>\mathrm{B}$ & $\mathrm{I},=\mathrm{S}$ & 1,181 & I. $>\mathrm{H}$ & B \\
\hline Penaeus aztecus & 252 & Fonly & $\mathrm{S} \geq \mathrm{I}$ & 215 & $\mathrm{I} .=\mathrm{H}$ & $\mathrm{C}$ \\
\hline Penueus setiferus & 307 & F only & $\mathrm{L}=\mathrm{S}$ & 1,227 & $\mathrm{~L}=\mathrm{H}$ & C \\
\hline Xanthidae & 207 & F only & I. $=\mathrm{S}$ & 17 & I. only* & C \\
\hline
\end{tabular}

NET: $\mathrm{F}=$ front net $\mathrm{ws} \mathrm{B}=$ back net.

FI.F. $; \mathrm{IH}: \mathrm{L}=$ long flumes $(10,20$, and $40 \mathrm{~m})$ vs $\mathrm{S}=$ : short flumes $(3 \mathrm{~m})$.

c TIIDF: $\mathrm{I}$. = low tide is $\mathrm{H}=$ high tide.

त See Fig. 10.

surviving (or escaping) the adverse environmental conditions (e.g., extrcmes of temperature, salinity, and dissolved oxygen) likely to occur if these organisms were to become trapped in a small pothole or burrow. Organisms in this classification were abundant in flumes and the majority were caught in the back nets of the long flumes. These organisms were more abundant in long flumes than in short flumes $(3 \mathrm{~m})$ and were rare or absent in seine samples since they rarely venture out into the "open" water of the creek. Fish in this group were all from the order Cyprinodontiformes, specifically: Fundulus pulvereus, Cyprinodon variegatus, Poecilia latipinna, and Adinia xenica. Of the common decapods caught., Uca sp. and possibly Sesarma sp. best fit into this category.

(B) Interior Marsh Users. These species utilize the interior marshes (but may require slightly decper water than the first group) and have a tendency to return to the creck edge at low tide. These species were also abundant in flumes and were more abundant in long flumes than in short flumes. Organisms in this group were commonly caught in back nets but were more abundant in front nets. These organisms were common in seine samples with higher catches from low-tide samples as compared to high-tide samples. The fish species that fit into this group, Fundulus grandis, and possibly Lucania parva, also belong to the family Cyprinodontidae. The two most abundant decapod spccies, Palaemometes sp. and Callinectes sapidus, also fit into this category.

(C) Edge Marsh Users. The third habitat-use pattern describes both resident and transient species that utilize the marshes along the creek edge at high tide but apparently do not penetrate into the interior marshes ( $>3$ in from the creck), except possibly during extreme flooding events. These species return to the creek and many remain in the shallow water along the creck cdge during low tide. Species in this category were abundant in flumes and caught only in front nets. Catches of these species were not significantly different between long flumes and short flumes, indicating no significant use of interior marshes. These organisms were abundant in scine samples along the 

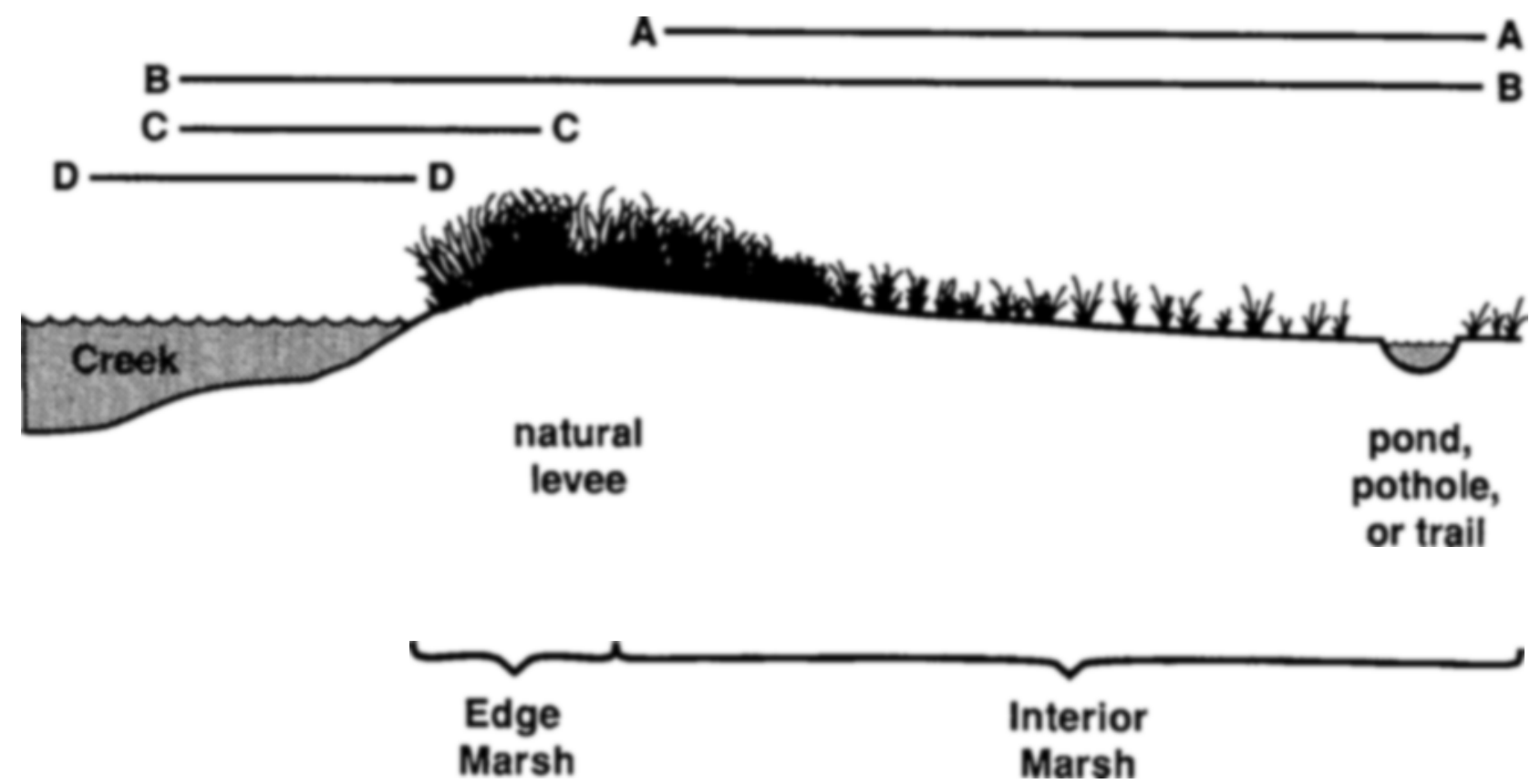

Fig. 10. A schematic elevation profile of the marsh creek bank with streamside effect (natural levee). Lines A-A, B-B, C-C, and DD represent patterns of marsh utilization by fish and decapod assemblages described in the text and in Table 7 (habitat use categories $A, B, C$, and 1 ), respectively).

marsh edge and were gencrally more abundant in low-tide samples. Included in this catcgory were resident species such as Fundulus jenkinsi, Gobiosoma bosc, Gobionellus boleosoma, and Menidia beryllina, and Xanthid crabs. Commercially important transient species, including spotted seatrout (Cynoscion nebulosus), Penaeid shrimp (Penaeus aztecus and $P$. setiferus), and possibly striped mullet (Mugil cephalus), were also included in this group.

(D) Marsh Subtidal Group. The last habitat-use pattern describes species that utilize estuarine open-water habitats, including the shallow-water creek edge, but apparently do not utilize the flooded marsh surface. Organisms in this catcgory rarely, if ever, ventured onto the flooded marsh surface, based on their absence or rarity in flumes (occasionally found in front nets only). However, seine sampling results suggest that species within this catcgory utilizc the shallow-water creek-cdge habitat to varying degrees. Spccics within this category could be divided into two subgroups of creck-cdge habitat utilization based on differences between high-tide and low-tide scine catches. The first subgroup included two flatfish species, Symphurus plagiusa and Achirus lineatus, that were common in seine samples from the creek edge but had no significant differences between high-tide and low-tide seine samples. Fish in the second subgroup were more abundant in high-tide than in low-tide seine samples, and included important transient species such as Anchoa mitchilli and probably Brevoortia patronus and some Sciacnid species.

\section{Discussion}

Based on these results we accept all three hypotheses stated in the Introduction. The results of the flume net and seine sampling indicate that flooded marshes are utilized primarily by decapod crustaceans (shrimp and crabs) and resident fish (Cyprinodontidac and Gobiidae; Hypothesis \#3). Transient fishes were less abundant on flooded marshes and primarily used the edge marshes ( $\mathrm{Hy}$ pothesis \#2). Utilization of flooded marsh habitats is highly variable among species in these wetlands. Some species stay in the marsh as long as it is flooded and take refuge in small ditches and potholes at low tide; others only use the edge marshes or venture into the interior marshes and return to the creek as the water drops; other species rarely, if ever, get up on the marsh. Therefore, we conclude that there are important species-specific patterns of marsh use by estuarine organisms (Hypothesis \#1). Here we summarize the individual species uses of the marsh and integrate our results with the results of others. 


\section{SPECILS Comparisons OF MARSI USH: DFCAPODS}

Grass shrimp (Palamonetes sp.) were the dominant organism using the flooded marsh surface in this and other studies (Zimmerman and Minello 1984; McIvor and Odum 1986; Rozas and Odum 1987; Limmerman 1989; Rozas 1992a, b). All life stages, from the smallest juveniles that could be retained in the mesh to gravid adult grass shrimp, were caught in flume and seine samples. Grass shrimp were not identificd to species because they were so abundant and identification to species is difficult and time consuming; however, from those that were identified and from the salinity range sampled, it appears that Palaemonetes pugio was the dominant species. Zimmerman (1989) listed threc species of grass shrimp ( $P$. pugio, $P$. vulgaris, and $P$. intermedius) in a higher salinity site in I ouisiana and found that they all showed a similar preference for vegetated over nonvegetated habitat. Grass shrimp were significantly more abundant in long flumes than in short flumes and in low-tide is high-tide scine samples. Some were caught in back nets (up to $40 \mathrm{~m}$ inland), although most (99\%) were caught in front ncts. Grass shrimp apparcntly use the marsh surface including the interior marsh whenever it is flooded, and most return to the creck at low tide. The use of flooded interior unarshes by grass shrimp was also documented by Kncib (1991) and Rozas (1992a). Because of the abundance of Palcemonetes species, their ability to accelerate the breakdown of detritus, and their importance as forage for other estuarine species, this movement of grass shrimp on and off the marsh surface with the tides may provide a major biological mechanism for the transport of encrgy (primary productivity) from intertidal marshes to the open estuary (Welsh 1975).

Penacid shrimp were common in flume net and seine samples but were much less abundant (by two orders of magnitude) than grass shrimp. Only juvenile penaeids were caught and these were transient specics that move out of the estuaries as adults. White shrimp ( $P$. setifemus) were equally abundant in long and short flumes, but unexplainably, brown shrimp ( $P$. aztecus) were more abundant in short flumes. Also, these two penaeid species were never caught in back nets, indicating that their use of the flooded marsh is limited to the edge $(<3 \mathrm{ml})$. Greater numbers of both species were caught in low-ticle seine samples, but the numbers were not significantly higher than hightide catches when log-transformed data were tested with an $\triangle N O V A$.

Studies in flooded Texas salt marshes (Zimmerman and Mincllo 1984; Zimmerman et al. 1984) showed that brown shrimp have a strong selection bias for vegetated habitat, particularly as small juveniles, whereas white shrimp were equally abundant in vegetated and nonvegetated areas. $\Lambda$ similar pattern was found in the laboratory, where the selection of vegetative cover by brown shrimp was shown to be an advantage for avoiding some predator species (Minello and Zimmerman 1983). Kneib (1991) used a "flume-weir" to sample nekton in the interior of a Georgia salt marsh, and reported white shrimp to be the most numerically important transient species. Rozas (1992a) often caught penaeid shrimp in his lift nets located on the marsh surface, and reported brown and white shrimp to be equally abundant.

Blue crabs (Callinectes sapidus) were caught in flume nets mostly as juveniles, but some adults were also caught in the front nets. Although differences between long and short flumes were not as pronounced as for grass shrimp, blue crabs were most abundant in 40-m flumes and several juveniles were caught in back nets, thus documenting the use of interior marshes by juvenile blue crabs. The higher abundance of bluc crabs in low-tide scine samples indicates that flooded marshes are important habitats for blue crabs; however, the edge marshes are probably utilized more than interior marshes, especially by larger juveniles and adults. Studies in Texas salt marshes ('Limmerman and Minello 1984; Thomas et al. 1990) reported that juvenile blue crabs were always significantly more abundant in flooded vegetated habitat than in adjacent nonvegetated areas. Other studies have found blue crabs (especially juveniles) to be one of the more abundant species using the flooded marsh surface in salt marshes (Hettler 1989; Zimmerman 1989; Kncib 1991; Rozas 1992a, b) as well as in tidal freshwater marshes (McIvor and Odum 1986; Rozas and Odum 1987).

Mud crabs (Xanthidae) were relatively common in the flume samples and apparently use only the edge marshes, since they were caught in equal abundance in all flume lengths and never caught in a back net. Although they were uncommon in seine samples (probably because of their ability to burrow to avoid seines), the mud crabs caught in seines were caught almost exclusively in low-tide samples. This observation provides evidence that mud crabs utilize the flooded marsh surface. Mud crabs were rare or only occasionally caught in Atlantic coast marshes (Rozas and Odum 1987; Hettler 1989) but were commonly found in flooded vegctation in another I ouisiana salt marsh by Zimmerman (1989).

Fiddler crabs (U/ca sp.) were commonly caught in flumes and almost exclusively in the back nets of the long flume treatments. Fiddler crabs were 
never caught in seine samples along the edge of the creck. Fiddler crabs use interior marshes and apparently avoid the open water of the creek, instead seeking refuge in burrows or potholes in the interior marsh at low tide. Wharf or marsh crabs (Sesarma sp.) were commonly caught in back nets $(39 \%)$, but there were no significant differences in catches between front and back nets or between long and short flumes. Only one wharf crab was caught in a scine sample (at high tide). Wharf crabs apparently use interior marshes but seem to show some preference for creck edge (natural levcc) marshes. Both $U / c a$ sp. and Sesarma sp. were commonly seen on the marsh surface at low tide, and tend to scurry away or retreat to burrows or potholes when approached. Because of their atmphibious and burrowing behaviors and their ability to climb out of flumes, fiddler and wharf crab abundances are probably underestimated since they are not forced into the cod-end nets as the water cbbs. Zimmerman (1989) collected $100 \%$ of fiddler crabs and $96 \%$ of wharf crabs from vegetated habitat in his study comparing vegetated to adjacent nonvegetated liabitats in a I couisiana salt marsh.

\section{SPECIES COMPARISONS OF MARSI USE: RF.SIIDF.NT FISHES}

Crobiosoma bosc was the most abundant fish caught in flume nets and the second most abundant fish caught in the seinc samples. This resident species was only caught in fromt nets. There were no significant differences between catches from long and short flumes and they were more abundant in lowtide seine catches (Category C, Table: 7). Naked gobies apparently move onto the marsh surface when it floods but remain near the creck edge. Naked gobies were also the most numerous and frequently caught fish species found in drop samples along the marsh edge in the Barataria Basin, Louisiana (Rakocinski et al. 1992; Balt. et al. 1993). In a Texas salt marsh, naked gobies were the most abundant fishes in drop samples, with $81 \%$ caught in vegetated (vs adjacent nonvegetatcd) samples at high tide (7immerman and Minello 1984). Other studies that sampled the saline marsh and edge habitats have found this species to be one of the morc abundant fishes utilizing this habitat (Peterson 1986; Hettler 1989; Ro7as 1992b).

Another resident goby, Gobionellus boleosoma, was somewhat less abundant than (x. bose in the flume and scine samples but showed the same pattern of marsh utilization. This species was also commonly caught along the salt-marsh edge and on the flooded marsh surface in other studies (Peterson 1986; Hettler 1989; Zimmerman 1989; Baltz et al. 1993).

Several species of (yprinodontid fishes were commonly caught in both front and back nets of the flumes. The use of flooded marshes by this group of fishes is well documented (Butner and Brattstrom 1960; Kneib and Stiven 1978; Weisberg ct al. 1981; Talbot and Able 1984; Kneib 1984, 1986, 1991; McIvor and Odum 1986; Lipcius and Subrahmanyam 1986; Rozas and Odum 1987; Rozas et al. 1988; I Iettler 1989; Rozas 1992a, b). Differences in marsh utilization patterns among the different cyprinodontid species can be inferred from the flume and scinc catch results. Three species (Cyprinodon variegatus, Adinia xenica, and Fundulus pulvereus) utilized the interior marshes and residual pools of water at both high and low tides (Category A, Table 7). Another cyprinodontiform fish (Poecilia latipinna, Fam. Poccilidac) also fits into this pattern of marsh utilization. Fundulus grandis and Lucania parva also utilized the interior marshes at high tide but apparently returned to the creck at low tide (Catcgory B, Table 7). Fundulus jenkinsi was the only cyprinodontid species that was commonly caught along the marsh edge, but it apparently did not utilize the interior marshes (Catcgory C, Table 7).

These different patterns of marsh utilization may reflect an evolutionary partitioning of this habitat that allows these cologically similar species to coexist. Weisberg (1986) compared four sympatric species of Fundulus on the Atlantic Coast (Delawarc) and suggested that competitive exclusion, rather than physiological barriers, may be the more important factor in controlling spatial segregation of these species. Forman (1968) suggested that differences in anatomy and feeding behaviors defined separate niches for five Cyprinodontid species and allowed for the coexistence of these species on a I ouisiana barrier island. The factors controlling the habitat partitioning among the (sulf of Mexico cyprinodontid species need more investigation.

()n the Atlantic Coast, Iundulus heteroclitus has been shown to move on and off the marshes with the tides to feed on invertcbrates on the flooded marsh surface (Kneib and Stiven 1978; Weisberg et al. 1981; Roras et al. 1988). These fish in turn are preved upon by larger predators (fish, crabs, and birds), thereby providing an important link (mechanism) in energy transfer between the intertidal marsh and adjacent subtidal waters (Valiela et al. 1977; Weisberg and Lotrich 1982; Kneib 1986). Fundulus grandis, the Gulf Coast ecological equivalent to $F$. heteroclitus, is reported to feed on the flooded intertidal marshes (Rozas and I aSalle 1990 ), and therefore probably performs a similar finction in the cnergy dynamics of Gulf Coast estuaries.

Several cyprinodontid species, $F$ grandis (Grec- 
ley and McGregor 1983), $F$. heteroclitus (Tavlor et al. 1977, 1979), F. pulvereus and Adinia xenica (Greeley 1984), reportedly utilize the flooded intertidal marshes for spawning and have evolved a spawning pattern that is correlated with the biweekly spring tides during the breeding season.

Menidia beryllina were less abundant in flume samples than the other resident spccies but were often caught in flumes and werc abundant in scine samples, especially at low tide, indicating some marsh surface utilization. Catches from long and short flumes were not significantly different, and all but one of the $67 \mathrm{M}$. beryllina caught in the flumes came from the front nets. These results imply that their use of the marsh is mostly limited to the edge. Menidia beryllina have been reported to be abundant along the marsh edge (Peterson 1986; Rozas 1992b; Baltz. ct al. 1993) and common on the marsh surface (Mclvor and Odum 1986; Rozas $1992 \mathrm{a}, \mathrm{b})$. However, when adjacent vegetated and nonvegetated habitats werc sampled at high tide (with drop samplers), M. beryllina were more abundant in nonvegetated habitats (Zimmerman and Minello 1984; Zimmerman 1989). A similar species, Menidia menidia, has also been collected from flooded salt marshes along the Atlantic Coast (Hettler 1989; Knicb 1991). Menidia menidia is generally an open-water schooling species found in tidal creeks and near-shore estuarine zones but is reported to spawn in the flooded intertidal vegetation (Butner and Brattstrom 1960; Fay et al. 1983).

\section{Sphoirs ComparisoNs OF MARSH Úse: TRLISIFNT FISHFS}

Transient fishes are those that spend only a portion of their life cycle (usually the juvenile stage) in the estuary, and include many economically important species. Only two transient species (Cynoscion nebulosus and Mugil cephalus) were caught in sufficient numbers in the flumes to infer direct use of the flooded marsh habitat. Both of these species were only caught in the front nets and were equally abundant in long vs short flumes. This result suggests they use the marsh surface only at the edge (<3 m from creek).

Scagrass beds are reported to be the preferred nursery habitat for juvenile Cynoscion nebulosus throughout much of their range (Perret et al. 1980; I assuy 1982; Mercer 1984). In estuarics where extensive seagrass beds are lacking, shallow, saline-marsh shoreline areas are probably the primary nursery habitat for juvenile $C$. nebulosus (Peterson 1986). Several recent studies have reported capturing juvenile spotted seatrout from the flooded marsh surface (I lettler 1989; Knicb 1991; Rozas 1992b), and others have reported greater catches in flooded vegetation when compared to adjacent nonvegetated habitats along the marsh edge (Zimmerman and Minello 1984; Zimmerman 1989; Rakocinski et al. 1992). Small juvenile spotted seatrout apparently utilize the shallow water along the marsh edge at low tide and move onto the marsh surface when it floods probably to feed and to avoid predators. Marsh use by spotted seatrout is probably restricted to the edge, because they were equally abundant in short and long flumes. Interior marshes may be more important in marshes that are inundated more often or deeper, such as those on the Atlantic Coast where spotted seatrout have been reported from interior marshes (Knieb 1991).

Although not extremely abundant, juvenile striped mullet (Mugil cephalus) were commonly caught in flumes in these marshes and from a nearby marsh (Rozas 1992b). These results indicate that mullet utilize the flooded marsh surface to some extent. The data from this study suggests that marsh use by mullet is limited to the edge; however, we have observed large juvenile mullet in the interior of other marshes during deep $(>0.5 \mathrm{~m})$ flood tides. In a follow-up to this study, we captured several mullet in pit traps within flumes on the marsh ( $15 \mathrm{~m}$ from the creek) at a site closer to the Gulf of Mexico that floods deeper and more often than the present sudy site. In another Louisiana study, Rozas (1992a) reported that $M$. cephalus was one of the more abundant fish species caught on the marsh surface in lift nets. Knicb (1991) reported that Mugil spp. are the most abundant transient fish species in his flume-weirs located in the interior of a salt marsh in Georgia. Ilettler (1989) reported that Mugil curema and $M$. cephalus were the sixth and ninth most abundant fish species (respectively) in his block-net samples from a flooded salt marsh in North Carolina, but he was unable to determine their extent of penetration into the interior marshes. Although the present study indicates that mullet utilize the marsh only near the edge (Catcgory C, Table 7), other studies suggest that mullet may be one of the few transient fishes that utilize interior marshes (Category B).

Two nektonic filter-feeders, Anchoa mitchilli and Brevoortia patronus, and two demersal flatfishes, Achimes lineatus and Symphurus plagiusa, were common in scine samples but were rarely or never caught in flumes (Category D, Table 7). This result indicates that they utilized the shallow water along the marsh edge but rarely, if ever, utilized the flooded marsh surface. Anchoa mitchilli was the most abundant fish species in seine samples and was significantly more abundant in high-tide samples. Brevoortia patronus were also more abundant 
in high-tide seine samples, but the differences were not significant because the total numbers caught were small. A relatively low number of menhaden were caught in seines in this study because seine samples were not collected in the winter and early spring when postlarval and juvenile menhaden are abundant in the estuaries. A. mitchilli and B. patronus are two of the more abundant species found in estuarine, open-water habitats (Gunter 1936, 1938; Herke 1971; Perret 1971; Wagner 1973) and along the marsh edge (Peterson 1986; Rozas 1992b; Baltz. ct al. 1993) in I ouisiana cstuaries. Anchovies and menhaden are frequently caught in drop-samples along the marsh edge but are rarely caught in samples containing vegetation (Zimmerman and Mincllo 1984; Zimmerman 1989; Rakocinski et al. 1992). These are mostly open-water species that may utilize the shallow creek-edge habitats at high tide, when the water at the edge is deeper, possibly to avoid predators or strong currents. Fore and Baxter (1972) reported increased catches of Brevoortia patronus larvae on chb tides along the edge of a tidal pass in Texas, and suggested that these immigrating larvae moved to the slower moving waters along the shore to avoid being swept back out of the estuary during ebb tides.

Although bay anchovies were caught in flumes, the numbers were low relative to their abundance in high-tide seine samples. In Atlantic Coast marshes with a greater tidal range, bay anchovies were commonly taken from the flooded marshes with flume nets (Rozas et al. 1988) and block nets (I lettler 1989), but none were caught on the interior marsh with flume-weirs (Knieb 1991). Rozas et al. (1988) reported that bay anchovy was the only common fish species that was more abundant in creck-bank flumes than in rivulet flumes. Bay anchovies are open-water, filter-feeders that may utilize the shallow-water marsh-edge habitat at high tide but probably do not penetrate into the flooded marsh vegetation except perhaps in sparsclyvegetated, decply-flooded marsh edges. A close association with the marsh edge at high tide could account for the presence of bay anchovies in flume net and block net samples, since these passive sample gears are see at high tide and, by design limitations, may sample a small amount of open-water (nonvegetated) habitat at the creek edgc.

No Gulf menhaden were caught in flumes. However, Rozas (1992b) captured 226 small Gulf menhaden in his flumes. I.ikc bay anchovies, juvenile Gulf menhaden are filter-feeders and may be incidentally captured in flumes if they feed along the marsh edge at high tide. Gulf menhaden undergo a distinct transformation in morphology and fecding habits during the time they are in the estuary. Pre-transformed larval menhaden $(<30-33 \mathrm{~mm}$
TL) are carnivores that selectively feed on zooplankton, whereas post-transformed juveniles and adults are omnivorous filter-feeders (Lassuy 1983). A selective feeding strategy would seem to be more effective among the stems of vegetation, but there was no evidence of utilization of the flooded marsh surface by small postlarval menhaden. In studies conducted along the Atlantic Coast, Hettler (1989) did not report any Brevoortia tyrannus from his block-nets, but Knieb (1991) caught a few (most $>30-\mathrm{mm}$ TL) in his flume-weirs in the interior marsh. The low abundance of menhaden collected from marsh-surface as compared to more open-water habitats is evidence that this important "estuarine-dependent" species does not significantly utilize the flooded marsh habitat.

Achirus lineatus and Symphurus plagiusa and other flatfish species have been captured from the flooded marsh surface in small numbers with block nets (Hettler 1989) and flumes (Rozas 1992b; this study) but not from the interior marshes (Kneib 1991; Rozas 1992a; this study). Symphurus plagiusa are relatively common along the marsh edge in shallow-water marsh habitats but are more often caught in samples with no vegetation (Zimmerman and Minello 1984; Zimmerman 1989; Rakocinski et al. 1992; Baltz et al. 1993). These and other small flatfish species are relatively common in estuarine, open-water habitats, as they often show up in estuarine trawl surveys (Herke 1971; Perret 1971; Wagner 1973) and in the bycatch of shrimp trawl fisheries (Gunter 1936). Morphologically, the flatfishes appear to be better designed for feeding in open-water habitats than among the closely spaced stems on the marsh surface, but the shallow-water, mud-flat habitat along the marsh edge may be very important to these flatfishes.

Several other transient fish species were caught in flumes and/or seines, bul their numbers were too low to confidently assign them to any habitatusc categories. Many common sciacnids (e.g., Micropogonias undulatus, Leiostomus xanthurus, Cynoscion arenarius, Bairdiella chrysoura, Sciaenopos ocellatus) and other species (Lagodon rhomboides, Arius felis) that are commonly caught in trawl and scine surveys in Louisiana cstuarics (Gunter 1936, 1938; Norden 1966; Herke 1971; Perret 1971; Wagner 1973; Pcterson 1986) were rarc or absent in flume samples. These are all considered to be estuarine-dependent transient species, but the analysis of flume data indicates that they do not directly utilize the flooded marsh habitat or they were not present in this area of the estuary during this study. None of these species were abundant in seine samples, although no samples were taken during the winter and spring when juvenile Atlantic croaker, spot, and red drum are most abundant in the es- 
tuaries. Some of these species may be more abundant in higher salinity portions of the estuary and could possibly utilize the marsh surface in marshes that flood deeper and more regularly.

Spot (Leiostomus xanthurus) are reported to be one of the most abundant estuarine transients utilizing the tidal crecks (W'cinstein 1979; Weinstein and Brooks 1983) and flooded salt marshes (Hetther 1989; Knieb 1991) on the Atlantic Coast. On the Gulf Coast, spot are abundant in shallow openwater areas (Herke 197I) and along the edges of salt marshes (7immerman and Mincllo 1984; Peterson 1986; Rozas 1992b), but none were caught in our flume or seine samples. Rozas (1992b) caught only seven spot in his flumes but caught 97 in beam trawl samples along the marsh edge. In drop samples along the marsh edge, spot were morc often caught in samples without vegetation (Zimmerman and Minello 1984; Baltz et al. 1993). Spot may not utilize flooded marsh vegetation to the same extent on the Gulf Coast as they do on the Atlantic Coast because of our smaller tidal range.

Cnlike spot, juvenile Atlantic croaker (Micropogonias undulatus) are rarcly found in shallow-water tidal crecks or flooded marshes on the Atlantic Coast but are common in decper channel habitats (Weinstein 1979; Weinstein and Brooks 1983; Hetther 1989). This apparent spatial segregation may reduce competition between these two morphologically similar species that are both abundant in the estuary during the same scason. This mechanism may be less important in the microtidal estuaries on the Gulf Coast, where salinity may play a more important role in habitat partitioning. Although these two species are often caught in the same trawl samples, particularly in mesohaline open-water areas in Gulf estuaries, spot are often more abundant in higher salinity portions of the estuary, whereas croakers are more abundant in lower (oligohaline) salinities (Perret 1971; Thompson and Forman 1987; Zimmerman ot al. 1990). Atlantic croaker are often the most abundant sciaenid caught in Louisiana estuarine surveys in shallow marsh creeks and small lakes, as well as in open bays and channels (Gunter 1938; Norden 1966; Herke 1971; Perret 1971). Juvenile croaker are also relatively common along the marsh cdge in I.ouisiana but not usually as abundant as juvenile spot in this habitat (Peterson 1986; Baltz et al. 1993). The absence (or rarity) of $\Lambda$ tlantic croaker in flumes and other collections from the flooded marsh (Hettler 1989; Kuieb 1991; Ro7as 1992a, b; this study) indicates that flooded marsh surfaces are not a primary nursery habitat for this species.

Juvenile sand seatrou (Cynoscion arenarius) are one of the more abundant species in I ouisiana es- tuarine surveys and in the bycatch of shrimp trawl fisheries (Gunter 1936, 1938; Norden 1966; Perret 1971; Herke et al. 1984), yet they are uncommon or rare in samples from the flooded marsh and edge habitats (Peterson 1986; Rozas 1992a, b; Baltz et al. 1993; this study). The primary nursery habitats for juvenile sand seatrout are probably the open-water estuarine bottoms and therefore they are susceptible to capture in trawls. In contrast, juvenile spotted seatrout, as discussed above, utilire the flooded marsh and shallow waters along the edge as a primary nursery habitat. This spatial segregation presumably reduces competition between these two morphologically similar species and allows them to coexist in the estuary during the same (summer) scason. The segregation of these two $(y-$ noscion species by habitat has been documented in Louisiana marshes (Peterson 1986) as well as in Florida grass bed habitats (Springer and Woodburn 1960).

Hardhead catfish (Arius felis) is another spccies that, like Atlantic croaker and sand seatrout, is seasonally common in open-watcr estuarine trawl surveys (Gunter 1938; Perret 1971; Wagner 1973) but is much less common along the marsh edge ( $\mathrm{PC}$ terson 1986; Baltz et al. 1993). Iardhead catfish have never been reported from the flooded marsh surface (IIettler 1989; Kneib 1991; Rozas 1992b; this study).

Pinfish (Lagodon rhomboides) are reported to utilize the flooded marshes adjacent to channels in a North Carolina salt marsh (Hettler 1989) but were not found in the interior of a salt marsh in Georgia (Knicb 1991). We caught only five pinfish in flumes and none in seine samples; however, Rozas (1992b) caught 84 in flumes and 126 in trawls along the marsh edge at a nearby marsh of higher salinity. Pinfish showed a preference for flooded vegetation and were most abundant in mesohaline and polyhaline marsh habitats in Galveston Bay, Texas (Zimmerman and Minello 1984; Zimmerman et al. 1990). Pinfish are common along the salt-marsh edges in Louisiana (Peterson 1986; Baltz et al. 1993) and may utilize the flooded edges of marshes in higher salinity marshes.

Silver perch (Bairdiella chrysoura) are common along salt-marsh edges in the Barataria estuary, Louisiana (Peterson 1986; Baltz et al. 1993). Although rare in our flume and scine samples, Rozas (1992b) reported silver perch to be relatively abundant in his flume and beam trawl samples from a higher salinity marsh within the same estuary. On the Atlantic Coast, silver perch were commonly found on the flooded marsh surface (Hettler 1989; Kncib 1991), and although they were not as numerous as spot, they were more abundant than spotted seatrout in both of these studies. It there- 
fore seems likely that in areas where they are abundant, silver perch will utilize the flooded marsh habitat, at least near the edge.

Juvenile red drum (Sciaenops ocellatus) are also common along salt-marsh edges in the Barataria estuary, Louisiana, particularly in higher salinity marshes close to the Gulf of Mexico (Peterson 1986; Baltz et al. 1993). (nly three red drum were caught in flumes and only four in seines during this study. In a higher salinity area, Rozas (1992b) caught only seven red drum in his flumes, but caught 66 in beam trawl samples along the marsh edge. Hettler (1989) reported a few red drum in his block-net samples from a salt marsh in North Carolina, and Kneib (1991) caught only two red drum in 271 samples from the intcrior of a salt marsh in Georgia. Zimmerman and Minello (1984) reported 12 out of 13 red drum were caught in drop samples containing vegetation. larger juveniles and subadult red drum forage among sparse vegetation along the marsh edge and juveniles are caught in seines along the edge in high salinity marshes (Peterson 1986). Juvenile red drum are rarely, if ever, caught in trawl samples away from the marsh edge in estuarine surveys (Gunter 1938; Norden 1966; Herke 1971; Perret 1971; Wagner 1973). The marsh-cdge habitat is very important to juvenile red drum (Peterson 1986), but their use of the flooded marsh surface is apparently limited to the sparse vegetation at the edge, at least in Louisiana.

\section{CONCLUSIONS ANI MANAGEMENT IMPLICATIONS}

In I ouisiana estuaries, the flooded interior marsh surface is an important habitat for marshresident fish (Cyprinodontiformes) and decapods (Palaemonetes sp. and $U c a \mathrm{sp}$.) but is probably not directly utilized by most transient fish and decapod species. Of those transient species that do use the marsh surface at high tide, most are only using the edge marshes $(<3 \mathrm{~m}$ into the marsh). This is not to say that these interior marshes are not important to the survival of transient "estuarine-dependent" organisms. The importance of emergent. marshes as a source of detritus for detrital-based food chains is well documented (e.g., Darnell $1958,1961,1967$; Harrington and Harrington 1961; Day et al. 1973; Deegan and Thompson 1985). The small resident fishes and grass shrimp that utilize the interior marshes provide a very important food source for larger estuarine-transient carnivores (e.g., spotted scatrout and red drum), especially in the fall and winter when cold fronts cause extremely low tides forcing these forage species into open waters. Furthermore, we did not determine the relative value of the marsh interior vs the edge for its use as a refuge or food source for organisms smaller than caught by the nets (3-mm mesh). Further, we measured biomass and numbers, not growth and predation rates. It is possible that species rarely found on the marsh surface are nonetheless dependent on the marsh for a brief period to sustain their populations. More importantly, the segregation of the marsh into spatial parts that are more or less important in terms of fisheries production is premature, in our opinion. Wetland-water couplings are complex. Knowledge of fisheries habitat use is not complete without understanding of, for example, the evolutionary relationships, predator-prey feeding networks, sediment resuspension and deposition, and microbial interactions.

Because the vegetation is so dense on the natural levee and the water depth, even at the highest levels sampled, never exceeded $25-30 \mathrm{~cm}$, it is likely that most fish entering this marsh from the creek did not cross the natural levee and therefore were not utilizing the interior marsh surface. Those fish that are using the interior marshes are marsh-resident species that probably gain access through rivulets, muskrat trails, and sinall ponds and retreat to these areas at low tide. The densities of these marsh-resident species were probably underestimated because flume walls restrict lateral movement over the marsh and because several potholes and muskrat trails within the flumes held water and provided refuge for these fish at low tidc where they could avoid being captured in cod-end nets. These marsh-resident species probably would have been more effectively sampled with pit traps, similar to those used in flume-weirs (Kneib 1991) and lift nets (Rozas 1992a), placed in low areas within the flumes.

A follow-up study is now in progress to compare utilization of marshes with and without well-developed natural levees, and to sample higher salinity marshes that are closer to the Gulf of Mexico and have a greater depth, frequency, and duration of flooding. This follow-up study is a test of the organism use of the edge vs the interior marshes using only two flume length treatments and using pit traps within these flumes to more effective sample the interior marshes.

Much emphasis is being placed on marsh management and restoration projects in Louisiana as a response to the rapid loss of marshes in Louisiana. Most marsh management plans in operation (or proposed) involve alterations of the marsh hydrology through impoundment or semi-impoundment via levees and water-control structures. Levees placed along a shorcline create obvious barriers to the movement of fish or crustaceans between the open-water and the marsh behind the levee. Water- 
control structures, such as fixed-crest weirs, have been shown to create barriers to the transport of estuarine-dependent fish and crustaceans that may result in decreased fishery productivity of the marsh open-water areas (Herke et al. 1992). Watercontrol structures also tend to dampen the daily tidal range in the marshes behind the structure and it is not known what impact this change in hydrology has on the use of these marshes by fish or on the overall productivity of the marsh. Besides altering fish access to the marsh surface, a change in the tidal regine of the marsh may also effect the export of primary (detritus) and secondary production from the marsh surface to the adjoining estuarine waters. Many economically important estuarine-dependent species (shrimp, crabs, and finfish) have adapted their feeding patterns to this daily tidal pattern. $A$ change in the hydrology of a marsh could result in a change of the community structure of organisms using that marsh. More information is needed on how fish utilization of marsh habitats is influenced by different hydrological regimes before we can begin to predict the full impacts of marsh management on fishcries. This type of information is also essential for planning marsh creation or restoration projects, if the objective is to create a marsh that functions as a fisheries habitat. A well-vegctated marsh that is not regularly inundated and not accessible to fishes and invertebrates may look like a successful project, but will not be as productive as a natural stable or deteriorating deltaic inarsh. The results of this study (and others) suggest that man-made marshes should be designed to maximize the edge habitat, have a gradual sloping edge profile (minimize levec effect), be well dissected by small drainage fcatures, and flood and drain on a regular tidal schedulc. In other words, man-made marshes should mimic the natural marsh morphology and hydrology.

\section{ACKYOWLFDGMENTS}

We thank E. Swenson and J. Lee and several others at the Coastal Ecology Institure and Coastal Fisheries Institute at Louisiana State I niversity who helped so willingly in the ficld. F. Swenson also maintained water-level gauges and provided the water-level data. L. Rozas provided advice on flume net constuction and sampling, and the I.ouisiana Universities Marine Consortium staff provided numerous forms of assistance that contributed to the field work. Particular appreciation is owed to the following who meticulously sorted samples: S. Kaswadji, 11. Pharl, S. Van Vu, and F. Aubert. C. (.. McIvor and one unidentified reviewer made several constructive comments that helped to improve the manuscript. We also thank the Louisiana $\mathrm{L}$ and and Exploration Company for permission to conduct research on their property. This study was funded by the National Marine Fisheries Service, Habitat Conservation Division, through an Intergovernmental Personnel Act assignment to (;.P

\section{ITERATLRE CITED}

Bal:\%, D. M., C. Rakocinski, and J. W. Flef., Fr. 1993. Microhabitat use by marshedge fishes in a I.ouisiana estuary. Environmental Biology of Fishes 36:109-126.

BOESTH, D. F. AND R. E. TuRNER. 1984. Dependence of fishery species on salt marshes: The role of food and refuge. Estuaries $7: 460-468$.

Bozeman, F. L., JR. AND J. M. DFAN. 1980. The abundance of estuarine larval and juvenile fish in a South Carolina intertidal creck. Estuaries 3:89-97.

BuTNer, A. AN B. H. BRATTSTROM. 1960. Local movements in Menidia and Fundulus. Copeia 1960:139-141.

DAR.F.1., R. 1958 . Food habits of fishes and larger invertebrates of Lake Pontchartrain, Iouisiana, an estuarine community. Publications of the Institute of the Marine Srience of Texas 5:353-416.

DARNeli, R. 1961. Trophic spectrum of an estuarine community, based on studies of I.ake Pontchartrain, Louisiana. Ecolog) 42:55:3-5t58

DARNELI., R. M. 1967. Organic detritus in relation to the estuarine ecosystem, p. 376-383. In G. F. Lauff (ed.), Estuaries. American Association for the Advancement of Science publication no. 83. Washington, ID. C.

DAY, J. W., JR., W. G. SMrTh, P. R. Wagiver, àd W. C. SToWr. 1973. Community structure and carbon budget of a salt marsh and shallow bay estuarine system in Louisiana. Center for Wetland Resources. Louisiana State University, Baton Rouge, I.ouisiana. Publication no. LSL'-SG-72-04.

DFF.MN, L. A. AND B. A. THOMPSON. 1985. The ecology of fish communities in the Mississippi River deltaic plain, Chapter 4, p. 35-46. In A. Yanez-Arancibia (ed.), Fish Community Ecology in Estuaries and Coastal Iagoons: Towards an Ecosystem Integration. DR (R) UNAM Press of Mexico.

FAY, C. W., R. J. Nrtfs, AND (;. B. Pardif. 1983. Species profiles: I ife histories and environnıental requirements of coastal fishes and invertebrates (Mid Atlantic)-Atlantic silverside. United States Fish and Wildlife Service, Division of Biological Services, FUS/OBS-82/11.10. Lnited States Army Corps of Engineers, IR F.I.-82-4. $15 \mathrm{p}$.

ForF, P. L. ANI K V. BAXTER. 1972. Diel fluctuations in the catch of larval Gulf menhaden, Brevoortia pationus, at Galveston Entrance, Iexas. Transaction of the American Fisheries Society $101: 729-7.32$.

Forman, W. W. 1968. The ecology of the Cyprinodontidae (Pisces) of Grand Terre Island, I ouisiana. M.S. Thesis. Louisiana. State University, Baton Rouge, Louisiana. $115 \mathrm{p}$.

('RFFI.EY, M. S. 1984. Spawning by Fundulus pulvereus and Adinia xenica (Ciprinodontidac) along the Alabama Gulf coast is associated with the semilunar tidal cycles. Copeia 1984:797-800.

GRtiley, M. S. AND R. MACGregor. 1983. Annual and semilunar reproductive cycles of the Gulf killifish, Fundulus grandis, on the Alabama Gulf coast. Copein 1983:711-718.

(itinTer, (i. 1936. Studies of the destruction of marine fish by shrimp trawlers in I ouisiana. Louisiana Consemtation Revieu 5: $18-46$.

GLNTER, G. 1938. The relative number of species of marine fish on the Louisiana coast. The American Naturalist 72:77-83.

HARRINGiro:, R. W., JR. AND E. S. HARRINGTON 1961. Food selection among fishes invading a high subtropical salt marsh: From onset of flooding through the progress of a mosquito brood. Ecology 42:646-666.

Hr.RKF, W. H. 1971. Use of natural and semi-impounded Louisiana tidal marshes as nurseries for fishes and crustaceans. Ph.D. Dissertation. Louisiana State Liniversity, Baton Rouge, Iouisiana. $242 \mathrm{p}$.

Herke, W. H., B. D. Rogers, ANI F. E. KNennse.v. 1984. Habits and habitats of young spotted seatrout in Louisiana marshes. I ouisiana State L'niversity Agricultural Experiment Station Reseatch Report No. 3., Baton Rouge, louisiana. 48 p. 
I IERKE, W. H., E. E. K.TtidsFY, P. A. KNLDSFN. AND B. D. RoGERS 1992. Effects of semi-impoundment of I ouisiana marsh on fish and crustacean nursery use and export. North Amesican Journal of Fisheries Management 12:151-160.

HFtri.f., W. F., JR. 1989. Nekton use of regularly-flooded salt marsh cordgrass habitat in North Carolina, LSA. Marine Ecology Progress Series 56:111-118.

KNE.IB, R. I. 1984. Patterns in the utilization of intertidal salt marsh by larvae and juveniles of Fundulus heteroclitus (Linnaeus) and Fundulus laciae (Baird). Joumal of Experimenlal Marine. Biology and Ecology 8:3:41-51.

K.VElB, R. T. 1986. The role of Fundulus heteroclitus in salt marsh trophic dynamics. American \%oologist 26:259-269.

K.YFIR, R. T. 1991. Flume weir for quantitative collection of nekton from vegetated intertidal habitats. Marine Erology Progress Series 75:29-38.

KXFIB, R. 'T. ANI A. F. SIIVF. 1978. Growth, reproduction. and feeding of Fundulus heterorlitus (I.) in a North Carolina salt marsh. Joumal of Experimental Marine Biology and Ecologn 31 $121-140$.

LASSLY, D. R. 1982. Species profiles: I.fe histories and environmental reguirements (Culf of Mrexico)-the spotted seatrout. Linited States Fish and Wildlife Semice, Office of Biological Services. FWS/OBS-82/11.4. 13 p.

I ASsty, D. R. 1983. Species protiles: Life histories and environmental requirements (Gulf of Mexico)-Gulf Menhaden. Inited States Fish and Wildlife: Senvice, Division of Biological Services, FUS/OBS-82/11.2. Inited States Army Corps of Engincers, IR F.I $-82-4.13 \mathrm{p}$.

I.jpoits, R. N. ANn C. B. Stbrahmanyam. 1986. Temporal factors influencing killifish abundance and recruitment in Gulf of Mexico salt marshes. Fstuarine and Coastal Shelf Science 22: $101-114$.

MoIvor, C: C: AN W. F. OnL'N. 1986. The flume net: A quantitative method for sampling fishes and macrocrustaceans on tidal marsh surfaces. Fistuaries 9:219 224.

Mc:Ivor, C. C. ANo W. F. Oncin. 1988. Food, predation risk, and microhabitat selection in a marsh fish assemblage. Ecology 69:1341-1351.

Mr.Ro.R, L. P. 1984. A biological and fisheries profile of spotted seatrout, Cynosciom nelnelosus. Nonth Carolina Department of Natural Resources and Community Development, Division of Marine. Fisheries, Morehead Ciry, North Carolina. Special Scientific Report No. 40.87 p.

Minel.lo, T.J. AND R. J. Zimmrkmax. 1983. Fish predation on juvenile brown shrimp, Penams aztecus lves: The offect of simulated Spantina structure on predation rates. Journal of Experi mental Marine Biology and Erology 72:211-232.

Nixon, S. W. 1980. Between coastal marshes and coastal waters - A review of twenty years of speculation and research on the role of salt marshes in estuarine productivity and water chemistry, p. 437-535. In P. Hamilton and K. B. Macl)onald (eds.), Fstuarine and Wetland Processes. Plemum, New York.

Norinf., C. R. 1966. The seasonal distribution of fishes in Vermillion Bay, I ouisiana. Wiscomsin Arodemy of Srience, Arts and Letters 55:119-137.

OndM, W. E. AND E. J. Hran, 1975. The detrims-based food web of an estmarine mangrove community, p. 26.5-286. In I. E. Cronin (ed.), Estuarine Research, Vol. 1. Academic Press, New York.

Prekrer, W. S. 1971. Cooperative Gulf of Mexico estuarine inventory and study, Louisiana: Phase: IV, Biology. Louisiand Wildlife and Fisheries Commission, New Orleans, I.ouisiana.

Perker, W. S., J. E. Willek, R. O. W'ilitams, P. I. JOHANSF, 'T D. M(IImais, R. (.. Rallekson, AND W. M. Taltim. 1980. Fishery profiles of red drum and spotted seatrout. Gulf States Marine Fisheries Commission Vo. 6.61 p.

PrIfrsox, G. W. 1986. Distribution, habitat preferences, and relative abundance of juvenile spotted seatrout and red drum in the Caminada Bay estuary, Louisiana. M.S. Thesis. I ouisiana State University, Baton Rouge, I.ouisiana. 96 p.

RakociNski, C. F., D. M. BAIL, ALD J. W. Hi.f.G.R. 1992. Correspondence between environmental gradients and the community structure of marshedge fishes in a Louisiana estuary. Marine Erology Progress Series 80:135-148.

Rozas, L. P. 1992a. Bottomless lift net for quantitatively sampling nekton on intertidal marshes. Marine Fcology Progress Se ries $89: 287-292$

RoLAS, L. P. 1992b. Comparison of nekton habitats associated with pipeline canals and natural channels in Iouisiana salt marshes. Wetlands $12: 136-146$.

Ro\%A, I. P. AND M. W. LASAI.F. 1990. A comparison of the diets of Coulf killifish, Fundulus grandis Baird and Girard, entering and leaving a Mississippi brackish marsh. Estuaries 13: $332-336$.

RozAs, L. P., C. C. MCIVor, AND W. E. Ont:M. 1988. Intertidal rivulets and creekbanks: Corridors between tidal creeks and marshes. Marine Ecology Progress Sries 47:303-307.

Royas, I. P. ANn W' F. Oblir. 1987. Lse of tidal freshwater marshes by fishes and macrofaunal crustaceans along a marsh stream-order gradient. Estuaries 10:36-43.

SAS INSITUIF INC: 1985a. SAS I'scrs Cuide: Basics, Version 5 Fdition. SAS Institute Inc., Cary, North Carolina. 1,290 p.

SiS Institute Ive: 198.̄h. SAS Cisers Cuide: Statistics, Version 5 Edition. SAS Institute Inc., Cary, North Carolina. $956 \mathrm{p}$.

SAS INSITITF INC. 1985c. SAS/GRAPH Lsers Guide, Version 5 Edition. SAS Institute Inc., Cary, North Carolina. $596 \mathrm{p}$.

SPRINifr, V. (G. AN1) K. D). WoODBuRv. 1960. An ecological study of the fishes of the l'ampa Bar area. Flonida State Board of Consernation Professional Pape Series 1:1-104.

IAIBOT, (. W. ANI K. W. ABLE. 1984. (omposition and distribution of larval fishes in New Jersey high marshes. Estuaries 7 : $434-443$.

IAYLOR, M. II., L. DiMichfif, ANI) G. J. I.FACh. 1977. Egg stranding in the life cvcle of the mummichog, Fundulus het erorlitus. Copeia 1977:397-399.

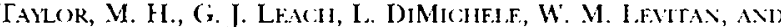
H. F. JAcoB. 1979. Iunar spawning cycle in the mummichog, Fundulus heteroditus (Pisces: Cyprinodontidae). Copeia 1979: 29) $1-297$.

THOMAS, J. T., R. J. 7IMMrRMAN, AND I' J. MINFI IO. 1990. Abundance patterns of juvenile blue crabs (Callinectes sapidus) in nursery habitats of two lexas bays. Bulletin of Marine Science $46: 115-125$

THOMPSON, B. A. AVD W. FORMAL. 1987. Vekton, Chapter 7. In W. H. Comner and J. W. Day, Jr. (eds.), The Ecology of Barataria Basin, Louisiana: An Estuarine Profile. Inited States Fish and Wildlife Service Biology Reports 85 (7.13). 165 p.

TIRNFR, R. F. 1992. Coastal wetlands and penaeid shrimp habitat, p. 97-104. In R. H. Stroud (ced.), Conservation of Coastal Fish I labitat. Procecelings of the 14th Annual Marine Recreational Fisheries Symposium. Coalition for Marine Conservation. Savannah, Georgia.

VAIf.IA, I., J. E. Wright. J. M. THAI, ANI S. B. VOI.kMAN. 1977. Growth, production, and energy transfonmations in the saltmarsh killifish Funduhus heteroclitus. Marine Biolog 40:135-144.

Wiaj, P. P. R. 1973. Seasonal biomass, abundance, and distribution of estuarine-dependent fishes in the Caminada Bay system of Louisiana. Ph.D. Dissertation. Louisiana State Liniversity, Baton Rouge, I ouisiana. $192 \mathrm{p}$

WeINSTEN, M. P. 1979. Shallow marsh habitats as primary nurseries for fislies and sleellfish, Cape Fear River, North Carolina. Fisheries Bulletin 77:339-357.

W'rissirin, M. P. AND II. A. Brooks. 1983. Connparative ecology of nekton residing in a tidal creek and adjacent seagrass meadow: Community composition and structure. Marine Erol ogy Progress Series 12:15-27. 
WEISBFrc; S. B. 1986. Competition and coexistence among four estuarine species of Fundulus. American Zoologist 26:249-258.

WEISBFRC; S. B. AND V. A. L.OTRICH. 1982. The importance of an infrequently flooded intertidal marsh surface as an cnergy source for the mummichog lundulus heteroclitus. An experimental approach. Marine Biology 66:307-310.

WhisberG, S. B., R. Whallis, AND V. A. LOTRu'11. 1981. Tidal and diurnal influence on food consumption of a salt marsh killifish Fundulus heteroclitus. Marine Biolog; 61:243-246.

W'E1sI, B. L. 1975. The rolc of grass shrimp, Pralaemonetes pugio, in a tidal marsh system. Ecology 56:513-530.

ZiMMERMAx, R. J. 1989. An assessinent of salt marsh usage by estuarine aquatic fauna at Grand Isle, I ouisiana. NMFS/SEC. Report to Environmental Protection Agency Region IV (Dallas). National Marine Fisheries Service Galveston Laboratory, Galveston, Texas. 27 p.
7.Mmprmax, R. J. A.ND T. J. Minello. 1984. Densities of Penaeus aztecus, Penatus setiferus, and other natant macrofauna in a Texas salt marsh. Estuanies 7:421-433.

ZimmFrman, R. J., T. J. Minfido, M. (. CASTIGLIONe, AND I). I. SMITI. 1990. Utilization of marsh and associated habitats along a salinity gradient in Calveston Bay. National Oceanic and Atmospheric Administration Technical Memorandum. NMFS-SEFC-250. $60 \mathrm{p}$.

Zimmermax, R. J., T. J. Misfi. o, ANi G. ZAMora, Jk. 1984. Selection of vegetated habitat by brown shrimp, Penaeus aztecus, in a Galveston Bay salt marsh. Fishenes Bulletin 82:325-336.

Rereived for considenation, July 31, 1992 Accepted for publication, March 31, 1993 